Portland State University

PDXScholar

Summer 1-1-2012

\title{
Atheist Scripts in a Nation of Religiosity: Identity Politics within the Atheist Movement
}

Jacqueline Frost

Portland State University

Follow this and additional works at: https://pdxscholar.library.pdx.edu/open_access_etds

Part of the New Religious Movements Commons, Quantitative, Qualitative, Comparative, and Historical Methodologies Commons, and the Theory, Knowledge and Science Commons Let us know how access to this document benefits you.

\section{Recommended Citation}

Frost, Jacqueline, "Atheist Scripts in a Nation of Religiosity: Identity Politics within the Atheist Movement" (2012). Dissertations and Theses. Paper 549.

https://doi.org/10.15760/etd.549

This Thesis is brought to you for free and open access. It has been accepted for inclusion in Dissertations and Theses by an authorized administrator of PDXScholar. Please contact us if we can make this document more accessible: pdxscholar@pdx.edu. 
Atheist Scripts in a Nation of Religiosity:

Identity Politics within the Atheist Movement

\author{
by \\ Jacqueline Frost \\ A thesis submitted in partial fulfillment of the \\ requirements for the degree of \\ Master of Science \\ in \\ Sociology
}

Thesis Committee:

Robert Liebman, Chair

Peter Collier

David Morgan

Portland State University

(C)2012 


\begin{abstract}
This thesis explores the use of identity politics within the atheist movement at both the national and individual levels. I conducted a content analysis of two national atheist groups and three best-selling atheist authors in order to assess the use of atheist identity politics at the national level. I then conducted 15 in-depth interviews with a sample of atheists in Portland, Oregon about their atheist identity and their reactions to and identification with national atheist movement strategies. Findings suggest that national atheist organizations and atheist authors are using a strategy of identity politics that encourage atheists to "come out" as atheists, complain about church/state violations, and criticize religion's influence in American society. They liken their movement to the gay identity movement and argue that as more atheists "come out", they will see less stigma and more respect towards atheists. However, individual atheists do not always identify with these movement strategies. Most participants said that atheism is not a particularly salient identity for them and thus most did not see themselves participating in atheist activism. Further, they implied that they experience little stigma in their everyday lives and are more concerned with promoting religious tolerance and secular policies. I argue that the lack of social identification with atheism, combined with limits to the gay analogy, are likely inhibitors to the success of an atheist movement.
\end{abstract}




\section{ACKNOWLEDGMENTS}

I would first like to thank the atheists who participated in this study. Your willingness to share your stories and opinions have enabled me to shed light on our understudied yet growing population. I would also like to thank my committee, Bob Liebman, Pete Collier, and David Morgan. You all played a key role as this thesis developed and what I took away from your classes and our conversations helped and will continue to help me grow as a researcher and a sociologist. Next, thanks to the study group that got me through grad school: Maura Pisciotta, Jen Rainer, and Jena Zarza. You ladies are amazing and I could not have done this without your continued support, constructive criticism, and willingness to join me in procrastination on occasion. Thank you to Frank Goulart for inspiring my research topic and thank you Sasha Fahrenkopf for keeping me honest and supplying the whiskey. 


\section{TABLE OF CONTENTS}

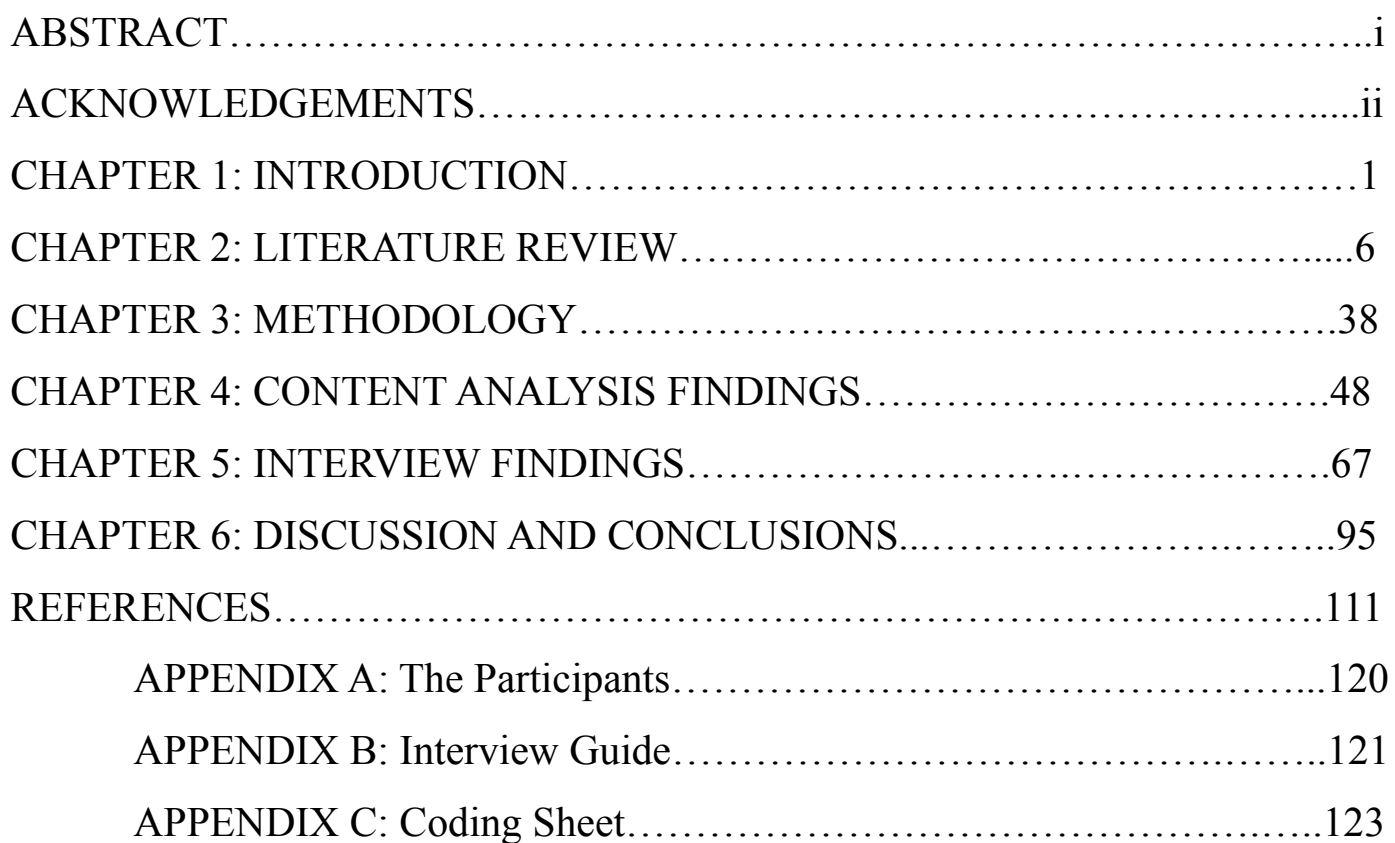




\section{CHAPTER 1: INTRODUCTION}

In 1969, the Library of Congress listed only thirty-two books on the topic of atheism, of which twenty-six were refutations (O'Hair 1969: iii). When you type "atheism" into the Library of Congress online search engine today, you get a list of 2,245 different books, references, bibliographies, and of course refutations, on the topic of atheism. One might think that this drastic increase can largely be attributed technological advances that allow for quicker and easier access to information. However, over half of the list provided was published after 1969. This means that technology alone cannot explain for the increase in atheist information.

A major factor in the increase in published knowledge on atheism is the major increase in religious disaffiliation seen not only in America, but in Europe and elsewhere. The proportion claiming no religion in America grew from five percent in 1972 to sixteen percent in 2007, and continues to grow (Pew Research Forum 2007). Take note that these numbers reflect those claiming "no religion," also referred to as "nones" by many researchers, which is not the same as identifying as an atheist. Only five percent of Americans say they do not believe in a god or supernatural spirit and only twenty-four percent of those non-believers call themselves atheist (Pew Research Forum 2007).

Atheists vary in their beliefs, but a very general definition of atheism is the rejection of the belief in any god or supernatural being and/or holding the very concept of God meaningless or incoherent (Baggini 2003). Another form of non-belief is agnosticism. An agnostic is uncertain about God's existence and/or claims no one can know for sure one way or the other (Zuckerman 2009). Additionally, freethinker, humanist, skeptic, and secular are terms that symbolize some form of non-belief. 
However, just because one is secular does not necessarily mean they are an atheist. For example, Hout and Fischer (2002) argue that the rise in non-belief in America is due to the increasing politicization of religion by the political right which has alienated some members of the political left. They contend that many of those in the "no religion" category remain privately religious or spiritual, but have become disenfranchised from organized religion. In fact, fourteen percent of Americans that do not believe in God selfidentify as Christian and four percent as Jewish (Pew Research Forum 2007).

There are two things one can take away from these varying statistics and definitions: One, religious disaffiliation and nonbelief are complex issues and require careful consideration when exploring sociologically. Two, Americans are seeing an increase in those who claim "no religion," including those who identify as atheist. However, despite their increase in numbers, non-believers, specifically atheists, are referred to as "the most distrusted minority in America" (Edgell et al. 2006). This stigmatizing process, compounded with a recent push of conservative religious politics, has caused an increase in activism in the form of identity politics and church/state legislation from non-believers. Even though there are numerous ways to identify as a non-believer, or believer who stopped going to church, the news media, as well as researchers, have begun to refer to this activism as an atheist movement. Indeed, news media has pointed to a "Growing Atheist Movement in America" (MacCallum 2006) with stories entitled "More Atheists Shout it from the Rooftop" (Goodstein 2009) and “Atheists - An Increasingly Outspoken Minority" (Williams 2008). Further, groups such as the American Atheists and the Freedom From Religion Foundation have been enacting legislation against church/state violations and have been buying billboard and bus ads to 
raise awareness about atheist identity and issues.

As a somewhat recent "convert" to atheism myself, I have always been fascinated with the ways in which people come to atheism, especially those coming from a strong religious background. I grew up in a very religious home in Wyoming and went through a long journey of self-exploration and questioning before coming to the conclusion that I was an atheist. This conversion occurred alongside my development as a sociologist. Research indicates that atheists and other forms of nonbelievers often lose their religious faith and beliefs due to the secular environment they are exposed to in college. During my four years as an undergraduate, I became increasingly intrigued with the sociology of religion (and irreligion) and scoured the internet for books and articles on atheism and its history. By the time I got to graduate school, I was pretty well versed in the popular atheist authors and their arguments, but knew little about atheism as a social movement.

During my first term in graduate school, I enrolled in a social movements class in which I did a project on the atheist movement's use of the coming out metaphor used by the gay rights movement, as well as other ways they were utilizing identity-based activism. While doing research for this project, I began thinking about my own atheism and the reasons why I did not participate in this kind of activism. Before conducting this research, the idea of being an "atheist activist" had never occurred to me. I had never thought of atheism as an identity, which made me wonder if this was true for other atheists as well. Was I just an uninformed atheist from Wyoming or were these national groups' strategies failing to reach other atheists as well? As social movement theories argue, a failure to recruit and mobilize new members can be the demise of a movement. So, I set out to better understand the messages being dispersed by these organizations and 
the ways these messages are and are not reaching individual atheists like myself.

The goal of this research is to explore this atheist movement, examining the strategies being used by its national leaders and representatives, as well as talking with individual atheists about their reactions to this recent movement activity and whether or not they identify with atheist movement strategies and goals. Many question the validity of holding an "atheist identity," however national atheist groups are utilizing identity politics as a major strategy in their movement.

The first chapter will review the theoretical and empirical research regarding identity and social movements and then transition into a discussion about atheist identity and activism in the United States. The second chapter introduces the methodology: a qualitative content analysis of atheist literature and 15 in-depth interviews with individual atheists in Portland, Oregon. The third and fourth chapters detail the findings from this research. Through thematizing numerous quotes from the literature and interviews, I outline the ways in which national strategies resonate with atheists on an individual level. The final chapter is both a discussion of the findings and of implications, limitations, and areas for future research.

Understanding the ways an emerging movement's strategies resonate with its constituents is an essential part of understanding the successes and failures of any social movement. It is important to understand the ways individuals who belong to certain social categories adopt or don't adopt that category membership as an important social identity, as this is may be one key in explaining the growth and sustainability of collective movements. Research indicates the recent collective action by atheists has indeed lessened their stigma. Four separate studies find evidence that perceived atheist 
prevalence is capable of reducing anti-atheist prejudice (Gervais 2011). Thus, a better understanding of the atheist movement's strategies and individual responses to those strategies will contribute to not only knowledge regarding religious identification and atheist identity, but also to understanding recent social movement mobilization in the United States. 


\section{CHAPTER 2: LITERATURE REVIEW}

This chapter provides a review of theoretical and empirical literature on identity construction, atheist identity and atheism in the United States, and atheism as a social movement. It situates this research within the conversation of social identity and social movement literature, as well as empirical findings regarding the ways atheists are building identity and using that identity as a resource to negate stigma and gain rights. Finally, it sheds light on certain gaps in research that this research will attempt to fill, such as a lack of understanding of the ways atheists who are not activists or group members react to atheist movement strategies and build their identities. I will begin with the theoretical background framing this research, setting up the idea of individual and collective identities as catalysts for social movements. Then I will transition into empirical research on atheism and atheist identity in the United States, discussing the few studies that have been conducted on atheist movement strategies and identity construction. Finally, I will outline a dramaturgical analysis of social movements in which movement leaders intentionally dispense scripts and manage performances in order to present a unified movement to the public. Taken together, the theoretical and empirical literature provides a framework for this research and concurrently addresses unanswered questions that this research seeks to address.

\section{Part 1: Theoretical Background}

\section{Identity as a Social Construction}

The ability to reflect and make oneself an object is what sets humans apart from other animals. Understanding how others see you allows you to adjust your actions and 
opinions based on others responses to your actions and opinions. Through reflection, people are able to organize their attitudes toward their social environment and thus construct an identity that is unique to their own experiences (Mead 1934). Howard (1991) states, "Identities are the consequence of being placed as a social object and appropriating the terms of placement for oneself' (Pp. 210). As we age and interact with others, we begin to develop a self, which is essentially the combination of all of the different identities one develops over time. The lines between self and identity are blurry and both have numerous definitions, but for the purpose of this study, I will define self as "an underlying sense of the continuity and essence of one's own person" (Howard 1991: 211) and identity as a view of oneself in terms of specific social locations. In sum, identity is a social construction because we co-create a shared understanding of society in the form of relationships and experiences we encounter in our daily lives. Our sense of self and identity are not entirely fixed, but fluid and often times go through drastic changes as we encounter new people, ideas, and experiences.

While a person may possess multiple identities based on multiple social relationships, not all identities are created equal. Erving Goffman (1963) discusses how society has set up a means of categorizing others quickly through stereotyping and grouping, as this allows us to move through life and interactions without having to relearn each new experience. This often times leads people to expect certain shared values and behaviors from others based on characteristics such as dress, speech, or religion before they meet them. With this process of categorization and stereotyping comes judgments, positive and negative, about the people who identify with or fall into specific categories. A stigmatized identity is one that is seen, by the majority, as a tainted 
or undesirable identity. Goffman states, "An individual who might have been received easily in ordinary social intercourse possesses a trait that can obtrude itself upon attention and turn those of us whom he meets away from him, breaking the claim that his other attributes have on him. He possesses a stigma, an undesired differentness from what we have anticipated"' (Pp. 5).

Goffman makes the distinction between discredited and discreditable identities. The former is a stigmatized identity that one can see, for example race, gender, or a physical disability. The latter refers to a stigmatized identity that is not outwardly visible, for example sexual orientation, political ideology, or religion. Due to the fact that discreditable identities are not visible, the person holding that trait can react in a variety of ways when interacting with others, though his actions fall into two categories: passing or affirming. To pass is to act as if one's stigmatized identity does not exist by not sharing it with another person. Conversely, one could chose to affirm that identity and reject the stigma it has been given; vocalizing their identity proudly as opposed to hiding it. This research focuses on a specific discreditable identity in America, atheism, and the ways atheists are reacting to that stigma, both as individuals and as a collective.

\section{Religious identity}

Stryker (1981) argues that identities are organized into a hierarchy of salience, which refers to the way one ranks how important certain identities are for them at certain times and around certain people. In addition, our identities are constantly overlapping and affecting each other. For example, a woman can identify as a woman at the same time she identifies with Islam. Her decisions as a woman will most likely be affected by her Islamic identity, and vice-versa, thus giving her religion and gender different levels of 
salience depending on the situation. However, religious identities tend to be especially salient for most people who hold them. Religion offers a "distinctive sacred worldview and eternal group membership, unmatched by identification with other social groups" (Anisman, Matheson, and Ysseldyk 2010: 60). Religion is not only a prevalent social identity in most societies, it is often accompanied by unfalsifiable belief systems, making it an especially important identity for those who are religious. Anismen et.al point out that if one truly identifies with a religion or belief system, it generally follows that they will soon see all other religions as wrong. These dogmatic beliefs can often give rise to intergroup conflict and religious groups have been known to start or participate in conflicts with other religious groups or groups who do not conform to their beliefs. In a later section I will discuss how rejecting a religious identity entirely, as atheists have done, can also be a particularly salient identity. Finally, Green (1999) argues that religion can also generate strong, collective identities that can serve as the basis for political action.

\section{Collective Identity}

When religion, or any other identity, is practiced by more than one person, it moves beyond a personal identity to a collective identity. Collective, or social, identities are shared definitions of a group that derive from their members' common interests, experiences, and solidarity; they can be produced through experience, ideology, commitment, or emotion (Bernstein 2008). Brewer (1991) explains that "social identities are categorizations of the self into more inclusive social units that depersonalize the selfconcept, where $I$ becomes we" (Pp. 476). Through this depersonalization, individuals slowly begin to mold their self-perceptions and behaviors to match that of the 
prototypical representation of those behaviors and attitudes that define the in-group's distinctive identity, thus transforming " individuals into group members and individuality into group behavior" (Brewer and Silver 2000: 154).

Identity theorists use the term in-group/out-group bias to describe the in-group favoritism that can occur in groups. By defining another group of people as the outgroup, one feels even more connected to their in-group (Edgell et.al 2006). When an individual feels an affinity for their in-group over anyone considered to be outside of their group, or the out-group, conflict can arise. This conflict can be as minor to the rivalry between high school sports teams to as devastating as Nazism. This type of conflict is common and many argue that it can strengthen the identities of both groups in the conflict. Further, a collective identity often makes an identity more salient to an individual than if that identity were only at a personal level (Brewer 1991).

However, it follows that if an individual can be stigmatized for an identity, than a group of individuals with that identity can also be stigmatized. However, identifying with a stigmatized group can have positive effects for an individual. Brewer (1991) argues that individual members of disadvantaged groups frequently perceive higher levels of discrimination directed against their group than they report against themselves personally. Further, individual activism is better predicted by feelings of fraternal deprivation ${ }^{1}$ than by feelings of personal deprivation. Additionally, when people with stigmatized identities band together to form a stigmatized group, they often times feel the sting of the stigma less. "What is painful at the individual level becomes a source of pride at the group level - a badge of distinction rather than a mark of shame. Collective identities buffer the

\footnotetext{
The perception that one's group is disadvantaged relative to other groups
} 
individual from many threats to self-worth" (Brewer 1991: 481).

\section{Transforming Collective Identities into Collective Action}

As with stigmatized individuals, stigmatized groups have a variety of options regarding how to react to their stigma. Brewer and Silver (2000) place these options into three broad categories: social mobility, social creativity, and social change. Respectively, a group can disassociate from its stigmatized category, find new ways of comparing themselves to other groups so that they evaluate themselves more positively than outgroup members, or they can attempt to change their status through collective action. When a group is stigmatized, it is often disadvantaged. Such groups often engage in collective action that addresses their stigma and disadvantages, seeking changes in their rights, status, or societal perceptions of their group. However, these movements do not simply occur spontaneously, but require a large group of mobilized, passionate individuals working as a collective.

Brewer and Silver (2000) argue that "the aggregate level of group loyalty among members of a social category constitutes a group resource in the form of mobilization potential" (Pp. 163). They discuss important traits a group needs to have in order to engage member identification and loyalty that will transform into successful collective action, arguing that a movement group needs to have explicitly agreed upon rules that define the boundaries between in-group and out-group members. Further, they describe numerous other converging processes that are needed to convert social identification into social action, including a heightened awareness of relative deprivation, strength of social identification, and a belief that collective action will be effective. 
The activism that results from a stigmatized group's successful engagement of collective action to address their stigma is often called identity politics (Armstrong 2002, Bernstein 2005, Cimino and Smith 2007). Bernstein (2005) defines identity politics as "the activism engaged in by status-based social movements...when a movement's identity is, to some extent, externally imposed and forms part of the basis for its grievances" (Pp. 48). Movements like the gay and women's movements are examples of stigmatized groups engaging in identity politics and these movements are often called identity movements.

\section{Identity Movements}

While social movements have historically been viewed in terms of class conflict, rational organization, and interest groups, new social movements ${ }^{2}$ transcend class-based conflicts and instead find structural roots in aspects of identity (Larana, Johnston, and Gusfield 1994). Mary Bernstein (1997) calls these movements identity movements. While identity plays a role in all social movements, when identity is the goal of a social movement, it is considered an identity movement. The movements strive to either gain acceptance for a stigmatized identity or deconstruct categories of identities such as man, woman, gay, straight, black or white. For Bernstein, an identity movement involves "expressing identity such that the terrain of conflict becomes the individual person so that the values, categories, and practices of individuals become subject to debate" (Bernstein 2008: 281).

Identity deployment is a strategy by which movements present and use their

2 Examples of "new" social movements include the gay rights movement, the feminist movement, the environmental movement, and the peace movement. 
identity as a resource in order to transform mainstream culture, its categories, values, practices, policies, and/or structures. She distinguishes between two types of identity deployment: identity for critique confronts the values, categories, and practices of the dominant culture and identity for education challenges the dominant culture's perception of the stigmatized minority. Bernstein (1997) illustrates identity deployment through the example of the gay rights movement. Gay rights activists employed identity for education when challenging negative stereotypes about lesbians and gay men, "such as having hundreds of sexual partners a year or struggling with uncontrollable sexual urges." They also utilized identity for critique when challenging the dominant cultural assumptions about the "biological 'naturalness' of gender roles and the heterosexual family structure" (Pp. 542).

Armstrong (2002) analyzed identity politics in the gay rights movement, noting that "identity politics suggests that creating and expressing alternative selves and alternative communities is the way to achieve change...change happens from the bottom up, through the creation of the desired society in miniature" (Pp. 19). This bottom-up strategy is called prefigurative politics, in which movement members form a community outside of the mainstream culture, strengthening their bonds and identities, and then eventually showing that united strength and identity to the mainstream. "Centered on the innovation of coming out, gay identity organizations highlighted identity building, pride, and visibility" (Pp. 21).

Bernstein (1997) argues that identity movements with access to the polity and/or a strong organizational infrastructure will seek policy change, emphasize sameness rather than difference, and will use identity for education rather than identity for critique. 
Conversely, "When an emergent movement lacks both political access and an organizational infrastructure or collective identity, then an emphasis on difference will be needed to build solidarity and mobilize a constituency. Such movements will tend to focus on building community and celebrating difference, as will those sectors of a movement marginalized by exclusive groups encountering non-routine opposition" ( $\mathrm{P}$. 541). Using the feminist movement as an example, Bernstein points out that the older, professional feminists deployed identity for education by emphasizing their similarities with men as well as engaging in more formal tactics, such as lobbying. Conversely, college-aged feminists who did not have this kind of access to the polity deployed more identity for critique. They criticized the place women held in America's patriarchal society and emphasized how being different than men was positive. The point is not so much that they differed in feminist ideology as in structural position to put it into politics.

The gay and women's rights movements are the most prominent examples of the use of identity politics. However, they are not the only groups to do so and a recent group of stigmatized individuals, atheists, have been using these same strategies in order to gain voice in American society. Many argue that a somewhat recent push of conservative, religious politics has caused an increase in religious disaffiliation and criticism/activism from non-believers (Hout and Fischer 2002, Jacoby 2004, Saxton 2009, Smith 2011). Examples of efforts "to legislate Christian literalism into statutory law" (Saxton 2009: 479) can be seen in legislation against abortion, gay marriage, stem cell research, teaching evolution in schools, and promoting safe sex and birth control, both nationally and internationally. Compounded with the intense stigma and "othering" of atheists, this politicization of religion has led to atheists responding as a collective. 


\section{Part 2: Atheist Identity and Activism}

\section{Atheists as "Other"}

Secularization, Non-belief and Atheism in America

Despite an increase in non-belief throughout history, with non-belief in God ranking fourth globally, after Christianity, Islam, and Hinduism (Zuckerman 2007), it has thus far failed to become an acceptable belief system in modern America (Berger 1999; Cimino and Smith 2007; Edgell, Gerteis, and Hartmann 2006; Hyman 2007).

Secularization theory posits that, as science and technology advance, the modern age will and has seen a decline of religion both in public and private life (Berger 1992). As technology advances in a society, science offers new methodologies and vocabularies for explaining authority and discussing the natural and social world, making religious explanations less salient (Lambert 2008). These processes threaten religion by reducing it to individually held beliefs (Berger 1992). Some argue that the end point of modernity, which is this ongoing process of advancement, is atheism (Hyman 2007). Others argue that secularization is not necessarily a natural byproduct of modernity, but that secularization was the successful outcome of an intentional political struggle (Jacoby 2004, Smith 2003). Secularization theory and its implications are subjects of debate among scholars and the theory that modernity is incompatible with religion, thus religion will eventually fade out of public and private life, has yet to be seen in many modern societies, including America (Berger 1992).

While there are laws requiring the separation of church and state in America, religion is still a major part of both private and public American life. Empirical findings 
suggest that while younger cohorts attend church services less than older cohorts, personal religious beliefs remain robust (Miller and Nakamura 1996). In an analysis of 12 years of General Social Survey data (1988-2000), Sherkat (2008) found neither an increase in atheism or a decrease in the certainty of belief. He also found no substantial cohort variations suggesting that cohort replacement would occur, leading to the eventual increase in atheism/decrease in certainty as older generations die out. This data echos previous studies that have found that as people age, marry, and have children, they are more likely to gravitate towards religion (Miller and Nakamura 1996; Roozen 1993). These studies indicate that secularization has not led to a decrease in American religiosity.

Berger (1992) argues that, due to modernity, there is a loss of the taken-forgranted aspects of religion, which makes fanaticism and religions claiming ultimate truths more appealing. This follows Durkheim's (1893) discussion of the transition from mechanical solidarity to organic solidarity as the division of labor in a society becomes more specialized. Mechanical solidarity is formed out of likeness: likeness of beliefs, values, and norms. Conversely, organic solidarity is based on difference, specialization, and tolerance. As societies become more organic, the questions of "why am I here" and "do I belong" become more difficult to answer, as no one truth is held above all others. This lack of homogeneity and ultimate truth can lead to anomie. Thus, members of modern societies often seek out forms of mechanic solidarity in religious identification. America is evidence of this phenomenon due to the majority of its inhabitants holding strong religious beliefs, despite its status as a developed country. According to a 2007 survey, only 5\% of American adults say they do not believe in God or a universal 
spirit, but only about a quarter (24\%) of these nonbelievers actually call themselves atheists (Pew Research Forum). In contrast, 95\% of Americans do hold some kind of supernatural belief, regardless of religious identification or church attendance. Compared to the rates of nonbelief in Sweden (85\%) and Denmark (80\%) (Zuckerman 2008), American rates of non-belief are miniscule. It is important to acknowledge that America's fervent religiosity is an anomaly (Zuckerman 2007). Societies with high amounts of nonbelief are normally those with a high rate of societal security and individual well-being in that society. ${ }^{3}$ Religion tends to wane when housing, food and healthcare are publicly available (Norris and Inglehart 2004). In fact, "nations marked by high levels of organic atheism $^{4}$ are among the healthiest, wealthiest, best educated, and freest societies on earth" (Zuckerman 2007:). Conversely, poorer nations that ranked lower in these categories, nations in Africa and Southeast Asia, have the lowest rates of atheism.

\section{A Brief History of American Civil Religion and Those Who Have Opposed It}

An important aspect of American religiosity, which is linked to its rejection of atheism as a legitimate identity, is civil religion. Civil religion is a term originally used by Jean-Jacques Rousseau in Social Contract. Its main components include the existence of a deity, the life to come, reward and punishment for virtue and vice, and the exclusion of religious intolerance (Hect 2007). Today, the term is used to denote the "American faith that transcends the crazy quilt pattern of denominational division" (Moore 1986: 202). It is a set of religious beliefs shared by most citizens about the sacred nature, ideals,

3 European nations with high rates of atheism, such as Norway, Sweden and Denmark, ranked highest in terms of life expectancy at birth, adult literacy rates, per capita income, and educational attainment.

4 Zuckerman notes the difference between "coercive atheism" in which non-belief is forced upon the society by a dictatorship, such as North Korea, and "organic atheism" in which non-belief emerges on its own, such as Norway and Sweden. 
character, and meanings of their country; a set of beliefs that are largely based in Protestant Christianity (Jacoby 2004, Lambert 2008).

American civil religion began to develop in the early 1800 s when states began disestablishing churches. In effect, churches lost their state funding and tax support on the "grounds that preference for one religious sect violated dissenters' rights of religious liberty" (Lambert 2008: 41). Once more and more states joined the disestablishment movement, churches became a part of the free marketplace. Now, instead of conflict between religious sects, churches operated at the same level and started working together. Soon, evangelical revivals broke out as the "new unity manifested itself in a concerted attack against infidels, especially through an evangelical revival that enjoyed widespread support among most denominations" (Lambert 2008: 42). These revivals called for a return to a Christian community and by the 1830 s the evangelical God had become "America's God" (Lambert 2008: 41-43). While the issue of slavery soon came to the forefront and split Protestants, the sense of a civil religion in America never faded.

Despite the overwhelming influence of Protestantism, and also because of it, secularists and non-theists have always been present, calling for separation of church and state and less religious influence in politics. In Freethinkers: A History of American Secularism, Jacoby (2004) discusses the ongoing conflict between theists and non-theists throughout American history, detailing how these opposing groups are in an ongoing battle to win the favor of the American public. When one group experiences a surge in popularity and success, the other rises up to protest. The acceptance of evolution contributed significantly to a major expansion of the freethought movement in the 1870 s and $80 \mathrm{~s}$ and the beginning of the $20^{\text {th }}$ century saw something of a "golden age of 
freethought" (Pp. 152). Throughout the $19^{\text {th }}$ and $20^{\text {th }}$ centuries, figures like Robert Ingersoll and Susan B. Anthony represented secular values and were active in protesting traditional religious practices, gaining rights for women and setting up public schools outside of church influence. However, after WWII, Catholicism's popularity skyrocketed and its condemnation of "godless communism" muted the "once robust American dialogue between secularism and religion" (Pp. 291); fearing McCarthyism and jail, most secularists kept quiet during this era in American history.

This silence ended in the 60s, a decade known for being a time of social change and shifting worldviews. "At the end of the self-satisfied 50s, few were prescient enough to foresee that the social ferment of the 60 s would reinvigorate American secularism and its opponents - in a fashion harking back not only to the golden age of freethought but the much earlier $19^{\text {th }}$ century conjunction of abolition and feminism" (Jacoby 2004: 316). The 60 s was a time of civil rights, antiwar, and sexual revolution movements, and with that came less tolerance for traditional religion and more tolerance for non-theist worldviews. However, as has always happened, this success triggered a backlash from the other side and the 70s and 80s birthed the Religious Right, a group whose goal of politicizing their Christian beliefs into law has seen substantial success. And the battle continues today. As Americans prepare for the 2012 election, religion is as much a topic of discussion as economics. Republican hopeful Mitt Romney has had difficulty garnering support from his Republican constituency due to his identification with Mormonism, and Rick Santorum hopes to win the majority touting fundamental Christian views of birth control and marriage. Thus, civil religion has not lost its luster, and continues to have a major influence in American society and politics. 


\section{Consequences for the irreligious}

As religion is deeply entrenched in American culture, the consequence is that religion is often equated with being a good American (Edgell et al. 2006). Additionally, while Americans accept and more recently welcome the diversity of religions within society, a lack of religion is seen as threatening and deviant. There has been increasing religious pluralism in postwar America due to increased immigration, which has caused the boundaries between religious groups to become less salient (Hout and Fisher 2001). "The weakening of internal boundaries between religious groups may heighten awareness of the external boundary between the religious and the nonreligious" (Edgell et al. 2006: 212). Studies show that Americans see a strong connection between religious faith and personal morality and that they feel religious identification is necessary for good citizenship (Hout and Fisher 2002; Edgell et al. 2006). In effect, atheists have come to “represent a symbolic 'other' against which some Americans define themselves as good people and worthy citizens" (Edgell et al. 2006: 214).

Today, this stigma is most apparent in public opinion, though there are some formal laws that illuminate America's opinion of atheism as well. In a 2003 survey which asked respondents which groups they felt did not share their vision of America, atheists topped the list with almost 40 percent followed by Muslims (26 percent) and homosexuals (23 percent). In a question asking respondents which group members they would disapprove of their child marrying, 48 percent chose atheists. Atheists were also at the top of the list of group members whom respondents would not vote for as a 
presidential candidate (Edgell et al. 2006). In fact, there are currently seven states ${ }^{5}$ with laws that ban nonbelievers from holding public office and/or bearing witness in court (Cimino and Smith 2007). While these laws are considered unenforceable because they violate the separation of church and state, they remain on the books and are symbolic of the boundary between believers and nonbelievers. Similarly, Weiler-Harwell (2008) discusses a 2000 Supreme court ruling that allowed the Boy Scouts to exclude atheists (and homosexuals) from membership, even though the organization receives many public benefits, including a federal charter and federal monies. These laws show that atheists face discrimination as well as the distrust suggested by recent surveys.

Public policy and opinions of public figures are indicative of what is acceptable and desirable in a society. Thus, the way that U.S. politics protects free expression in principle but in fact honors religion in public ${ }^{6}$ only perpetuates religion as a norm in society and non-belief as deviant (Bellah 1967, Edgell et. al. 2006, Moore 1986). When George Bush Sr. was campaigning for presidency as incumbent vice-president, he said in an interview, "No, I don't know that atheists should be considered as citizens, nor should they be considered patriots. This is one nation under God" (Sherman 1988). This sends a blatant message that atheism is un-American and unacceptable as an identity. Dawkins (2006) brings up a valid point in saying, "Try the experiment of replacing 'atheists' with 'Jews' or 'Muslims' or 'Blacks.' That gives the measure of the prejudice and discrimination that American atheists have to endure today" (Pg. 65).

\section{Atheist Identity}

5 These states include Arkansas, Maryland, Massachusetts, North Carolina, Pennsylvania, South Carolina, Tennessee and Texas.

6 Examples of religion in public include chaplains in U.S. Congress, tax exemption for churches, "In God we trust" on our money, overwhelming religiosity of American presidents, and "faith-based initiatives." 
The previous section detailed the ways people form identities through religion and how these identities are often very salient for those who hold them. But how does one develop an identity based on the rejection of religion? There is significant debate around the idea of forming an identity based on something that one does not believe in. However, researchers argue that atheism is indeed a salient identity for people, with many examples of atheists promoting their beliefs as adamantly as the religious (Cimino and Smith 2007, Anisman et al. 2010). Baggini (2003) argues that to see all things as being grounded in the natural world is a legitimate and defensible worldview that is experienced and lived out in practical ways. In addition, a disbelief in God has implications for perceptions of social norms and policies, especially in a country where those norms and policies have strong religious undertones. "Certainly, such a belief system also offers potential explanations regarding what can be known and what can exist and is likely to be of great import to those whose self-identification as an atheist is central... clearly more research is needed to disentangle the complexities in the making and maintenance of atheist versus religious belief systems and identity" (Anisman et al. 2010: 65).

Hunsberger and Altemeyer (2006) surveyed over 300 active atheists to determine how dogmatic, zealous, and religiously ethnocentric atheist activists were. "Of course, some of our informants do nothing more 'active' than read the club newsletter. But some really energetic atheists have had dramatic impacts on our society" (P. 11). In other words, being an atheist activist can mean simply joining an atheist group for social reasons or go so far as being a protestor for church/state separation. The researchers found that their active atheist sample held relatively high dogmatic beliefs ${ }^{7}$ compared to

7 Beliefs that are unchangeable and/or formed based off of unjustified certainty 
their rates of zealotry. ${ }^{8}$ While a large majority of the respondents felt their beliefs were true and conceded that it would take a lot of convincing evidence for them to change their views, most responded that they would not raise their children in their beliefs, choosing to let them make up their own mind, and relatively few approved of teaching atheism in public schools. However, both rates were low compared to a group of religious fundamentalists that were surveyed as a control. Finally, survey questions attempting to measure religious ethnocentrism ${ }^{9}$ found that active atheists were roughly as religiously ethnocentric as their religious fundamentalist counterparts. The atheists revealed a significant favoritism for those with similar beliefs and equally significant dislike for all religious groups, especially fundamentalists. In other words, very sharp lines were drawn between their nonreligious in-group and all "others" who had belief.

Smith (2011) argues that atheism, an identity for which the larger culture offers no validation, is not a ready-made identity like many religious affiliations. Most religions have a set of rules, absolute truths, and expected actions that converts adhere to from the moment of conversion (Anisman et al. 2011). Conversely, atheism is an identity formed out of a rejection of religion and has no stereotype or set of rules to follow. Smith uses the idea of the "not-me" or "not-self" to describe atheist identity. This is the idea that an identity can be formed around something one rejects (i.e. vegetarians, teetotalers, sexual abstainers) (Mullaney 2006). In this sense, Smith (2011) makes the argument that atheists form their identity around what they are rejecting in theism. While he found that his participants came to atheism differently, they all went through four general steps. First, they had to engage with theism, which is the norm in American society, with religious

Feeling so strongly about a belief that one is prone to proselytizing.

9 The formation of in-group/out-group biases based on religious affiliation. 
identification often being the default (Zuckerman 2009). Second, they questioned this theism, whether because of education or a bad experience with a particular religion. Third, they rejected theism and began forming an identity based off of that rejection. Finally, to fully internalize the atheist identity, the participants "came out" as atheist, a term coined by the gay rights movement that describes the way gay individuals privately and publicly came to terms with their contested identity (Anspach et al. 2007). Smith (2011) argues that this final step is crucial in forming an atheist identity. Although many experienced negative reactions by coming out, it also allowed for their atheist beliefs to move beyond merely a label to a salient aspect of their identity.

Bainbridge (2005) argues that atheism stems from a lack of social obligation. He found that atheists are less likely to have or want children, be married, feel obligated to their friends, and are more likely to be geographically mobile. This is a common theme in studies on atheism; the idea that atheists are anti-social, individualistic, and most do not attend/join groups, making it difficult to study them in group settings (Bullivant 2008). Indeed, a common metaphor is that organizing atheists is like "herding cats" (Dawkins 2006). However, atheists do join groups and engage in atheist activism. There are studies, though limited in number, examining atheist groups and atheism as a social movement (Cimino and Smith 2007; 2011, Hunsberger and Altemeyer 2006, Ritchey 2009), yet this area demands further research (Smith 2011). Questions remain about the strategies being used by atheist organizations, the reactions to those strategies by atheist individuals, and the ways in which atheists identify with a collective.

\section{Atheism as a Collective Identity}

The scholarly qualitative research on modern atheist activism is minimal and does 
little to discuss the actions of individual activists and perceptions of those actions.

However, the media has not overlooked atheist activists and reports that atheists have been organizing protests against church/state violations (Jacarino et. Al 2011;

Moszczynski 2009; Roberts 2010) and erecting billboards that promote a positive atheist identity and criticize Christmas and other religious traditions (Dolack 2010). The largest atheist group in America is the American Atheists, which had over 2,000 members in 2007 (Cimino and Smith 2007). The organization was founded by the infamous Madalyn Murray O'Hair, ${ }^{10}$ who played a large part in getting prayer taken out of schools in 1963. From that first group spawned numerous others and today there are atheist groups for every taste. Atheist Singles, Atheist Bikers, Vegan Atheists, Black Atheists, Foxhole Atheists, and the list goes on (Foust 2009). Most of these groups are for social purposes and do not have activist agendas (Foust 2009, Hunsberger and Altemeyer 2006), though some atheist groups organize and take part in protests, marches and campaigns promoting diversity and atheist acceptance (Cimino and Smith 2007, Ritchey 2009).

Foust (2009) interviewed atheists who attended atheist "meetups." She found that these groups were a place where atheists could feel comfortable, learn new things about religion and irreligion, and be around like-minded people. While the topic of atheism comes up, it is not the focus of discussion and groups members expressed simply liking the fact that they knew everyone around was an atheist. These groups form small communities that serve many of the same social functions that churches serve for the religiously affiliated; they are a place where people socialize and build bonds, but are also

10 O'Hair was known for her controversial, colorful, and often times outright caustic defense of atheism. She was an outspoken atheist in the 60s and was often referred to as "The Most Hated Woman in America." She was kidnapped and murdered in 1995 by an employee of the American Atheists (LeBeau 2003). 
a place for networking and trading professional services among atheists. Foust also discussed how atheists felt a public message promoting atheism would not be received positively by society. While some of her respondents did participate in activism, through renting billboard space, volunteering at soup kitchens, and promoting separation of church and state, these activities were geared towards fostering awareness and recognition of the atheist community, and respondents specified that they were not fighting specific battles, trying to convert others, or mock their beliefs.

Ritchey (2009) studied a group of atheists in Pennsylvania, the Atheist Station, and found that being a part of this group reinforced and strengthened the identities of its members. Gatherings were typically organized to either address a specific local issue of importance or simply to socialize with an outing. He described these groups as communities of practice, which are "groups of people who share a concern or a passion for something and they learn how to do it better as they interact regularly" (Wegner 1998: 4). As members became more involved, they progressed from the periphery to the center of practice, meaning they internalized their atheist identities as they progressively drifted away from the larger culture and toward the center of atheist subculture. In addition, they were more competent in deploying their atheist identity. "Competence for deployment was strengthened by the group members engaging in public debate through radio call-in shows, letters to the editors of local newspapers or direct action such as protests and speaking out at public meetings" (Ritchey 2009: 7). While members of the Atheist Station had internal disagreements, one being a divide between conservative and liberal atheists, they always came together when it came to public debates. Ritchey argues that when stigmatized identities are deployed in public arenas, it tends to foster group solidarity 
among the stigmatized, even if there are schisms within that group.

These groups are examples of what Bernstein (1997) calls community building and Armstrong (2002) would call prefigurative politics. Groups who are marginalized and have little organizational infrastructure will focus on building solidarity among themselves and distinguishing themselves from the majority. These groups accomplish this by allowing for a diverse group of atheists to come together and share ideas; reinforcing but also molding identities toward a collective. They enable individuals to go from having a personal identity, a trait that differentiates one from others, to a social identity, in which $I$ becomes we and self-worth is affected by the reputation and issues of the group as a whole (Brewer 1991).

\section{Atheist Activism}

Larger, national groups such as the American Atheists and the Freedom for Religion Foundation ${ }^{11}$ are known for their political action and publications promoting atheism and non-belief. American Atheists is responsible for court cases regarding nativity scenes in public areas, the erection of crosses to honor troops, and prayer rallies for political candidates (atheists.org). The Freedom from Religion Foundation has been in the spotlight for trying to block 2012 presidential hopeful Rick Perry from attending a prayer rally. They have enacted legislation against a national day of prayer, the posting of the ten commandments in public places, and the awarding of school credits for evangelical release times (ffrf.org). American Atheist and Freethought Today are

11 This group isn't specifically atheist, however, many of the atheist groups are inclusive to other forms of non-belief. 
publications that stem from these organizations. They include descriptions of the group's legal action, "deconversion" stories, narratives of atheists and their problems, and discussions of religion and its implications.

Aside from enacting legislation, researchers have recently been elucidating the ways in which atheists are using identity politics to gain voice and negate stigma. A major strategy used by the atheist movement is the "coming out" metaphor. Anspach, Coe, and Thurlow (2007) studied four national atheist groups, including American Atheists and the Freedom From Religion Foundation, and looked at these groups' websites and publications in search for "lateral appropriation of discursive capital, the process whereby the discursive capital of one marginalized group is usurped by another similarly marginalized group" (97). They found that these groups were remetaphorizing the use of the homosexual closet and coming out in order to "strategically establish relations of equivalence which allow atheists to invoke a more immediately recognized identity politics" (P. 97). The researchers discuss how this lateral appropriation occurs among movements often, with the women's suffrage movement likening their plight to slavery and homosexual groups using the rhetoric of women's and African-American rights movements.

This illustrates the feedback mechanism found within the protest environment. Groups look to other group's successes and failures when considering how and what to protest themselves. Thus, "protestors choose their repertoire from the available stock" of protest options (Crossley 2002: 128). In order for movements to succeed, they need to have a certain degree of knowledge and skill in the specific techniques of protest. Most importantly, a movement group needs to be able to judge which actions are legitimate in 
their specific time and place. "The institutionalized space for legitimate protest is carved out by way of protest itself; contenders are constantly innovating, but usually at the 'perimeter' of existing repertoires" (Crossley 2002: 129). Thus, movement groups tend to follow in the footsteps of recent movements that were successful before them. For instance, the atheist movement sees the gay rights movement as a model of success. The president of American Atheists states on their website, "But there is another closet which is hiding a different minority: atheists. Many of us, like many gays of previous decades, hide in the shadows due to fear of hostility and aversion to confrontations" (atheists.org).

Cimino and Smith (2007) argue that atheist groups have been confronted with the failure of progressive secularism in the United States and have thus internalized their minority status. Interviews with 37 members and leaders of atheist and secular organizations revealed that atheists felt like an "embattled minority" and instead of waiting for religion to wane, are focusing on building a niche for themselves. They found that atheists are seeking out groups and communities that resemble the church communities of their counterparts. In order to make these secular communities thrive, especially for atheists, many groups have extended their membership to include all forms of non-belief, as well as forms of liberal and non-conservative religions. McGrath (2004) argues that this has made atheism lose its cutting edge and is evidence of its need for members. Others argue that this inclusion will only make the movement stronger (Dawkins 2006). In order to acquire this array of new members, secular and atheists groups have resorted to proselytizing in the same way they condemn their evangelical counterparts for doing.

Cimino and Smith (2007) found the movement to be engaging in identity politics 
when using terms such as "coming out" and using their status as an "embattled minority" to form anti-discrimination support networks. "Their adoption of both the subcultural style of evangelicals and identity politics allows secular humanists and atheists to press for greater acceptance in American society while maintaining a vital subculture" (P. 423). Cimino and Smith (2011) also note a shift away from what they call institutional secularism, which focuses on legal proceedings and coalition building with religious organizations to a cultural secularism in which the movement is trying to discredit religion and advocate for change on a more individual level through argument and debate.

\section{"New" Atheism}

While the above groups have been in action for decades and generally receive little attention in the media, a surge of atheist authors writing caustic bestsellers has brought the issues these groups have been advocating for years to the public arena. New Atheism, as the intellectual movement behind the recent wave of books attacking religion has come to be called, includes books by Sam Harris (The End of Faith, 2004), Richard Dawkins (The God Delusion, 2006), and Christopher Hitchens (God is Not Great, 2007). These books aggressively target religion using a scientific perspective. They argue that civil religion should not be tolerated but countered and criticized by rational argument (Stenger 2009). They argue that even moderate forms of faith encourage extremism, and belief in any form of supernatural being or power should be criticized (Saxton 2009). Finally, they elucidate the evils of religion and its use in legitimizing violence and oppression (Peterson 2007). The response to these books has been mixed, even among 
non-believers, though their bestseller status indicates that they have grabbed the attention of the American public. "Clearly these works have tapped into a vein of public discontent with religious fundamentalism in the wake of horrific terrorist attacks in the United States and Europe as well as nearly a decade of dominance of American politics by a Republican party under the sway of the religious right" (Peterson 2007:803).

Criticisms of these books and their arguments, which often bleed into criticisms about the atheist movement in general, include the arguments that the authors are too harsh, too privileged, and offer little in the way of promoting action (Hutchinson 2011, Peterson 2007). Foust's (2009) interviews with atheists in North Carolina detail reactions from individual atheists to this literature. Most respondents disapproved of these authors, saying they were "preaching to the choir" and that their vehemence and bite are "responsible for keeping atheist a dirty word" (P. 62). They were hesitant to contribute to the "religion bashing" that these authors are so famous for and felt that this was an obstacle the atheist movement needs to hurdle. Conversely, some participants were converted by this literature and found that these books pushed them "from doubting to atheist." In addition, these books reaffirmed many participant's stances and gave them a sense of solidarity.

Cimino and Smith (2011) found similar answers among their sample of 105 atheists across major cities in America. All of the respondents were aware of the New Atheists, and many felt that their critiques were harsh, but most agreed with the overall argument and felt the books enabled a "greater sense of acceptance or support in society." (Pp. 30). Despite the mixed reactions, scholars argue that these texts are achieving exactly what they set out to do and atheism is now a hot topic in the media and public 
debate (Cimino and Smith 2011, Peterson 2007, Saxton 2009). Not only have they given atheists a sense of community, more than half of Cimino and Smith's (2011) respondents believed that theists who read these books would have a more positive view of atheists and atheism. What is "conceived as a confrontational device becomes an opening for the empowerment of an alternative discursive practice. These [unabashedly anti-religious discourses] don't have to conform to civility nor to the dictates of the general interest. They can be expressed for what they are: particular, regional, one-sided, and for that reason politically alive" (Carpignano et al., 1993: 116).

A final issue that some of these authors discuss is the idea of relabeling atheism due to its stigma. Dawkins and fellow "new atheist" author Daniel Dennett promote the use of the term "Brights" to encapsulate all forms of non-belief (Saxton 2009). The relabeling strategy calls for all non-believers to unite under one umbrella and call themselves Brights. As of January 2010 over 50,000 Brights registered from 186 nations (the-brights.net). Atheists in Foust's (2009) study took on the label "atheist" because they felt other labels such as "bright," "freethinker," and "secularist" were "cop-outs" and euphemisms (Pp. 73). More specifically, many felt that the label "Bright" was offensive to others, as it infers that those who are not "Brights" are "dim" in some way. Others felt less strongly and argued that atheism is stigmatized and they understood the desire for others to relabel themselves. Finally, one participant argued that, regardless of name, nonbelief will be stigmatized and they needed to focus on "taking back the term" (Pp. 74).

\section{Implications}

The research indicates that atheism has become a growing collective identity in America and that there are indeed examples of atheist identity movement activity. 
However, while the research indicates a use of identity politics among atheist organizations, there is little research that examines these strategies closely or the reactions by atheists to those strategies. Cimino and Smith $(2007 ; 2011)$ do talk to atheists about how they feel about new atheism, as well as look at secular humanist groups' reactions to the failure of progressive secularism through the use of identity politics, but do not discuss in detail the use of those strategies or the reactions to other strategies being used by the movement. Further, they do not address the ways individual atheists do or do not identify with a collective atheist identity. In addition, they focused on group leaders and members, leaving no understanding of how less active atheists are reacting. Foust (2009) helps to fill this gap, talking with atheists about relabeling strategies and experiences with atheist activism, but her research focuses on atheists in North Carolina, which leaves a gap in knowledge about how atheists in other parts of America are reacting and deploying identity.

Understanding the ways an emerging movement's strategies resonate with its constituents is an essential part of understanding the successes and failures of any social movement. Brewer and Silver (2000) argue that "social identification can be viewed as a group resource that is critical to the ability of a group to mobilize collective action among its members or to recruit group members into a social movement" (Pp. 154). Thus, it is important to understand the ways individuals who belong to certain social categories adopt or don't adopt that category membership as an important social identity, as this is key in understanding and explaining collective movements. Recent research indicates that the recent collective action by atheists has indeed lessened their stigma, with four separate studies finding evidence that perceived atheist prevalence is capable of reducing 
anti-atheist prejudice (Gervais 2011). Thus, a better understanding of the atheist movement's strategies and individual responses to those strategies will contribute to not only knowledge regarding religious identification and atheist identity, but also regarding recent social movement successes in the United States.

\section{Part 3: Studying the Atheist Identity Movement Dramaturgically}

"Identity deployment should be understood dramaturgically as the collective portrayal of the group's identity in the political realm, whether that be in city council hearings or at sit-ins in segregated restaurants.” (Bernstein 1997: 538). Dramaturgy, a perspective made popular by Goffman (1959), stems from symbolic interactionism and asserts that humans present themselves to one another based on cultural values, norms, and expectations. This presentation is much like a play, in which there are specific roles, props, and an audience. Thus, people (or actors) intentionally present, or act out, certain roles for certain audiences. Benford and Hunt (1992) utilize this perspective to look at social movements and analyze how movement leaders define and articulate power using dramatic techniques like scripting and staging.

Before discussing these techniques, it is important to define the role of social movement leaders. A social movement leader is not the same as a social movement organizer. Leader are people "who can serve as movement 'spokespersons' who put themselves forward or are selected by the media as 'stars' but are not accountable as leaders" (Reger 2007: 1352). Thus social movement leaders are not always necessarily the people organizing protests or even those who support all aspects of the movement they are said to be leading. They are often people who are lionized by the media and the 
public and become de-facto leaders or representatives of a movement group.

Scripting can be seen as a set of directions offered by movement leaders that "define the scene, identity actors, and outline expected behavior" (P. 87). These scripts are not strict guidelines, but rather they are emerging guidelines, giving movement actors behavioral cues and stock answers when unanticipated events or questions arise, yet they are flexible enough to allow for improvisation. Scripts are not to be confused with frames. "While framing provides actable ideas, scripting moves these ideas one step closer to enactment. It casts roles, composes dialogue and directs action" (P. 87). A movement member can look to the scripts constructed by movement leaders to answer the questions: Why take action? What action should I take? Who should I take action against? Will my actions make a difference? A major aspect of scripting is the construction of opponents, thus making movement members the "victims." When movement leaders vilify opponents, it "galvanizes and focuses sentiment." Movement actors are scripted as the protagonists and movement opponents are scripted as antagonists in the social movement drama. Scripts often call on emotions to dramatize ideas, using accounts of abuse of power and conversion stories to win people over. This gives movement members a sense of empowerment in that they are fighting for the abused and a sense of efficacy in that they see others can be converted.

A second dramatic technique Benford and Hunt (1992) detail is staging, in which movement members manage materials, audiences, and symbols. Performances by movement leaders and members need to be consistent and reflect the movement scripts, or the audience will see the performance as inconsistent. This involves the idea of dramaturgical loyalty, which is allegiance to a movement's constructed definitions or 
emergent norms. Movements strive to present an image of solidarity to outsiders, and when movement members fail to do so, "their actions not only upstage or parody collective performances, they tend to discredit movement attempts to sustain a unified image" (P. 96). Further, when a movement fails to present a unified front, they can be more susceptible to critiques from antagonists and often fail to recruit new members.

In sum, Benford and Hunt (2009) advocate for analyzing social movements as plays in which movement leaders intentionally construct and dispense scripts that inform movement members what to do, how to do it, and who to blame when doing it. In turn, movement members take these scripts and act them out, with varying degrees of success and compatibility with the original script. If the leader's scripts do not resonate with individuals or if the movement fails to present a unified front, the movement is less likely to achieve its goals.

\section{Integration and Summary}

The review of the literature has painted a picture of intolerance and stigmatization of atheists throughout American history. It discussed the implications of secularization and its failure to, thus far, eradicate religion in America, leaving atheists as outsiders. It outlined literature on identity movements, focusing on Bernstein's $(1997,2005,2008)$ discussions of the gay and women's rights movements. Building on this discussion, it highlighted the ways in which individual atheists are constructing identity and how atheist groups are utilizing the strategies Bernstein discusses in her literature. Finally, it outlines a dramaturgical analysis of social movements in which movement leaders intentionally dispense scripts and manage performances in order to present a unified 
movement to the public. Taken together, the goal of this research is to use Benford and Hunt's (1992) dramaturgical theory of social movements as a framework to analyze the ways in which atheist groups and individuals are engaging in the identity politics Bernstein describes. The following research questions are an attempt to understand the ways in which national groups are dispensing identity politics as well as the ways in which individual atheists are reacting to and deploying those same strategies:

1. What scripts are the leaders of the atheist identity movement dispensing?

In what ways are they utilizing identity politics? Are they likening their movement to the gay identity movement?

2. What scripts resonate with individual atheists?

Where do they get their scripts? How do they differ among individuals? What factors contribute to the different scripts chosen?

3. How do atheists deploy identity at an individual level?

Do they participate in atheist activism? Do they join online or face-to-face communities?

4. How do scripts dispensed by leaders and national groups compare to individual scripts and identity deployment?

Are individual atheists aware of the atheist identity movement? Do they agree with the movements goals and strategies? Do they identify with a collective atheist identity? 


\section{CHAPTER 3: METHODOLOGY}

In this chapter I discuss how I analyzed key atheist texts as well as how I collected and analyzed interviews with atheists in Portland, Oregon. I outline Bernstein's (1997; 2005 ; 2008) work on identity movements as well as a dramaturgical analysis of social movements (Benford and Hunt 1992) that guided the construction of interview questions and coding sheet categories, though both the interview guide and coding sheet evolved during data collection. Additionally, I discuss methods for qualitative data analysis, as shaped by Strauss and Corbin (1998). Finally, I acknowledge the limitations of this research, including my personal bias, subject and content recruitment, and methodology.

\section{Research Design}

This research utilizes a multi-method approach to data collection, combining two qualitative methodologies to obtain a richer understanding of atheist scripts and strategies. In order to address my research questions, I conducted a content analysis of two national atheist groups' literature and websites and three best-selling atheist author's non-fiction books. Second, I conducted 15 semi-structured, formal interviews with atheists in the Portland, Oregon area. This multi-method approach allowed me to verify the descriptive and interpretive validity of my findings, as well as explore multiple dimensions of this phenomenon (Johnson 1997).

The first portion of my research included analysis of atheist groups and literature, which allowed me to address my first research question: What scripts are atheist movement leaders dispensing and in what ways do they mirror identity rhetoric? The second portion of my analysis, in-depth interviews with atheists, allowed me to answer 
my second and third research questions: Which movement scripts resonate with individual atheists and how do they deploy their atheist identity? Once I completed these analyses, I was able to answer my final research question: How do scripts at the national and individual level compare and what are the implications?

Though my research is grounded in identity movement and dramaturgical theories, some aspects of grounded theory, as outlined by Charmaz (2006), were used. I collected data while simultaneously analyzing data and interview questions were molded and remolded based off of my initial findings. I also continued to review the literature throughout the data gathering process, which led to my research questions evolving over the course of the study.

\section{Why Qualitative}

Research examining atheism has been largely quantitative. Due to the fact that non-belief is multifaceted and somewhat abstract, people can be lumped into a non-belief category that they do not identify with (Bainbridge 2005). Therefore, studying one form of non-belief is quantitatively tricky because few share the same non-belief identity. Consequently, it is hard to know the meaning of responses gained through quantitative methods. Because the goal was to better understand a potentially burgeoning movement with an ever-changing array of identities and subjective experiences, a survey instrument was inappropriate. The survey instrument would have required me to foresee answers and form them into simple categories, which was not possible due to the lack of research in this area.

A qualitative content analysis of atheist literature was necessary to understand the 
tone, purpose, and strategies of those publications. Further, semi-structured interviews allowed participants to explain their atheism and discuss their reasons for joining or not joining groups, reading atheist literature, and participating in activism. Lastly, I wanted to examine what atheism means to those who identify as atheists; thoughts, feelings, beliefs, values, and assumptions are all involved in the construction of a belief system and faceto-face interviews can capture such interaction (Charmaz 2006). In addition, each stage of the research enabled data triangulation in order to ensure a valid and thorough understanding of atheist scripts and activism.

\section{Content Analysis}

\section{$\underline{\text { Data Collection }}$}

\section{National Groups}

Researchers identify the American Atheists, who publish The American Atheist magazine, and The Freedom From Religion Foundation, who publish the Freethought Today newspaper, as the largest and most representative groups of atheists in America (Anspach et. al. 2007, Cimino and Smith 2007; 2011). I chose to analyze all 2010 issues of The American Atheist and Freethought Today, the most current publications, to ensure I was attaining the most current information about the group. Additionally, I examine both groups' websites, analyzing their mission statements, posts about activism, and other sections of their websites dedicated to disseminating information about atheist identity and activism, for example tabs entitled "Take Action" and "Come Out of the Closet."

\section{Atheist Authors}

The second portion of my content analysis included literature published by well- 
known atheist authors. I chose to focus on three of the "New Atheists" to represent the literary leaders of atheism. While many other books on atheism have been published, these authors have sold the most books, topped recent bestseller's lists, are widely read by nonbelievers (Foust 2009, Cimino and Smith 2011), and are often cited as representatives and/or leaders of atheism (Anspach et.al 2007, Foust 2009, Peterson 2007, Saxton 2009, Stenger 2009). Books included God is Not Great (2007) by Christopher Hitchens, The End of Faith (2004) and its follow-up Letter to a Christian Nation (2005) by Sam Harris, and The God Delusion (2006) by Richard Dawkins.

\section{Data Analysis}

In order to analyze how atheist identity politics are being used at the national level, content from national groups and atheist authors were coded using a coding sheet (see Appendix C) that I built based off literature from Bernstein $(1997,2005,2008)$ and Benford and Hunt (1992). The sheet included questions about which scripts atheist leaders were dispensing, what actions they were urging atheists to take, who they were framing as their antagonist, and which identity movement strategies they were using.

\section{National Groups}

Using the coding sheet described above, I analyzed the 2010 issues of The American Atheist and Freethought Today. I examined each article (which included news stories, opinion pieces, narratives and conversion stories from atheist readers, and theological discussions), letters to and from the editor, student essays, special sections and blurbs (such as Atheist of the Month, "Overheard," a section of quotes from famous atheists as well as famous non-athiests, book reviews, and a monthly section devoted to 
detailing crimes committed by priests). When analyzing the groups' websites, I focused on their front pages, their "About Us" sections, and any sections devoted to activism or building community and/or atheist identity. For example, the Freedom From Religion Foundation has a section on their website devoted to their "Coming Out Campaign," which explains the campaign through text and pictures. They also have a tab at the top of their front page entitled "Get Invovled" with subheadings "Take Action" and "Billboard Campaign." The American Atheist website also has a page devoted to coming out, as well as a section entitled "Action Alerts," dedicated to keeping members updated on activism news.

\section{Atheist Authors}

To code the three major authors, I read their books in their entirety. While reading, I continually coded by filling out the coding sheet. Reading the books from beginning to end allowed for a better understanding of the tone and purpose of the book. Additionally, I accounted for all chapters of the book in order to identify which are most relevant to addressing my research questions. In the end, it was easiest, and most likely offered more valid data, to code the entire book.

\section{In-depth Interviews}

\section{$\underline{\text { Sample Selection }}$}

The sample for this study was found using convenience sampling. In order to identify key atheist groups and their members, I joined Meetup.com, an online social networking site that facilitates offline group meetings. This site had numerous atheist groups meeting in and around the Portland, Oregon area. I went to three different group 
meetings and obtained 9 participants by introducing myself and my research and simply asking if anyone would like to participate. Overall, non-group members were more difficult to obtain, as atheism is not a readily identifiable trait. Co-workers and colleagues put me in contact with people they knew who fit my criteria and the remaining participants in my sample were obtained in this fashion.

I conducted a total of 15 interviews. Fifteen was a large enough number to gain a representative sample, yet small enough to be a manageable masters thesis. Ten out of the 15 participants were male and a majority were Caucasian, though other races and ethnicities were represented, including Indian, Hispanic, African/Brazilian, Japanese, and Jewish. Ages ranged from 22 to 58 and all participants had at least some college education. The majority of the participants grew up in the West/Northwest (see Appendix A for a table detailing the participants). As a majority of atheists are educated, white, and male (Sherkat 2008), my sample is representative of the larger atheist population. However, the inclusion of a variety of ages and some varying ethnicities lends itself to more representative sample, as I get the perspective of non-male, non-white atheists as well. Sadly I could not track down a non-educated atheist, though I am positive they are out there and deserve further study. Criteria for inclusion in my sample included living in the Portland, Oregon area and identifying as atheist. I did not limit my sample to a certain definition of atheism, and in fact discussed what atheism meant to each participant and why they chose that label. Interviews were conducted face-to-face in my office at Portland State University and ranged from 30 minutes to an hour and a half. An interview guide (see Appendix B) gave structure, while also leaving room for unintended responses and discussions in order to ensure the interpretive validity of my findings (Johnson 1997). 
Interviews were designed to gather information related to the participant's experiences with religion growing up, how they came to atheism, how they talk about that atheism to others, where they get their information about atheism, and their opinions regarding atheist activism.

\section{Interview Implementation}

The interview questions evolved as each one was conducted, with the first two interviews being largely experimental. The first interviews were shorter and did not have as many probes and discussions as the later interviews did. However, as each interview progressed, the interview guide was slowly molded into a more valid and reliable instrument. Eight interviews were conducted in July and August of 2011, while I simultaneously analyzed content of atheist publications and conducted further research for the literature review. After this first round of interviews, I re-evaluated my interview guide by adding more probes and additional areas of discussion, guided by my initial interviews and a closer examination of the literature. The second round of interviews took place in November of 2011. While a third round of interviews would have been ideal, as respondents varied substantially in their identities and more participants would have lent themselves to a more representative sample, time constraints did not allow for a third round. Despite this limitation, the 15 interviews obtained did have significant recurring themes and the findings are sociologically important and grounds for further research.

I transcribed verbatim transcriptions of the recorded interviews to aid in a close analysis of the responses and to enable analytical coding. 


\section{Reading, Coding, Comparing}

I conducted open-coding (Strauss and Corbin 1998) on the published material and interviews. This included reading the data, highlighting salient quotes, and familiarizing myself with the similarities and differences among the different sources. I started to identify and note recurring ideas, concepts, and opinions. I then started to find commonalities amongst the texts and conducted axial coding ${ }^{12}$ (Charmaz 2006, Strauss \& Corbin 1998) in which I identified intersections and started to cluster categories. As key concepts started to emerge, I looked for commonalities and combined them into themes. Collapsing categories elicited major themes among the texts and interviews. Once I developed the dominant themes from each source, I examined all dominant themes across the various texts, stories, and interviews, looking for commonalities and divergences.

\section{Limitations}

While analyzing national atheist groups and representatives of the movement gave an in-depth look into the atheist movement as a whole, this study is not generalizable to all atheists and atheist groups. One important caveat of this research is the location in which it was conducted. Portland, Oregon has been found to be the third least-churched city in the nation, ranking only behind San Francisco and Portland, Maine, with fewer than one-third of Portland residents going to church on a weekly basis. However, despite low attendance rates, 71 percent of Portland residents identify as Christian (Nieslon 2011). Zooming out to look more broadly at Oregon, the state has the highest percentage

12 Axial coding "relates categories to subcategories, specifies the properties and dimensions of a category, and reassembles the data you have fractured during initial coding to give coherence to the merging analysis" (Charmaz 2006:60). 
of "nones" in the nation, with $27 \%$ nones to the national average of $16 \%$. Thus, Portland is a space that is more accepting of non-belief than many areas in the United States. In fact, three of my participants discussed how it was easier to be an atheist in Portland and how they even thought less about their atheism due to the wide acceptance of their beliefs in the city. Further, at least two of my participants moved to Portland for its secular atmosphere. Thus, the stigma experienced and the community available for atheists depends largely on where they are at geographically. Compounded with a small sample size, generalizability was largely irrelevant and, more generally, not the goal of this qualitative research (Charmaz 2006). While some data may be transferable to other similar (relatively liberal) situations where similar (well-educated) atheists are interacting and deciding whether to be part of a collective mobilization effort, findings from this study are not representative of all atheists in all areas. Research is starting to emerge on this topic (Foust 2009, Schutz 2012, Smith 2011) and researchers are looking at atheist identity formation and activism in places like South Carolina and Arizona, but further research is needed in this area.

Finally, my personal bias toward atheism is both a limitation and a strength, and something I remained cognizant of as a researcher. Before starting this research, I was a peripheral member of the atheist community, having a thorough knowledge of the atheist authors examined in this study, but having never attended a group meeting or joining an online group. Having come to atheism myself just a few years ago, I was somewhat aware of recent movement activity and had obtained a few atheist contacts prior to starting this research. I set out to be reflexive, actively engaging in critical self-reflection about my biases and predispositions (Johnson 1997), though I understand that being a 
supporter of the movement will influence my analyses and conclusions, as well as interviewee responses. However, being a member of the movement provided me access to interviews and groups that I would not otherwise have had access to. 


\section{CHAPTER 4: CONTENT ANALYSIS FINDINGS}

\section{Come Out, Complain, and Criticize: Scripts Dispensed by Atheist Leaders}

The analysis of atheist publications, including national atheist groups and wellknown atheist books, revealed overwhelming evidence of atheist identity politics. Found in all three sources were examples of calls for atheists to build community, come out, educate the public, and criticize organized religion. While there are many similarities among the scripts used by these sources, they each have a distinct script to offer. American Atheists emphasize a need to come out, the Freedom From Religion Foundation encourages its readers to complain by writing letters to their congress people or taking legal action to address a church/state separation issue, and the atheist authors strongly urge readers to criticize religion openly.

One important distinction between the atheist groups and the popular authors was the difference in tone and purpose. The two atheist groups are very moderate, and while they are often harsh critics of organized religion, they are sure to balance those critiques with statements about being tolerant of others and respecting their religious opponents. Conversely, the New Atheists are much more intense and hyperbolic, using caustic prose that berates anyone who holds a supernatural faith, urging readers to do the same. In regards to purpose, the group websites and literature are more prone to have clear movement scripts that promote action and affirm atheist identity while the authors tend to focus more on the negatives of religion through discussions of science and philosophy.

Finally, references to the atheist movement being similar to the gay identity movement can be found throughout all of the sources, though were most prominent in the group literature and websites. In fact, the New Atheists rarely discuss atheism as a 
movement and focus on discussing atheism as a personal identity. This rhetoric is present in the group literature, but they were much more prone to talk about atheism as a collective identity and the need for closeted atheists to come out and support an emerging movement.

\section{American Atheists - Come Out}

The American Atheists provide the most explicit movement scripts, setting up organized religion as their antagonists and appealing to the in-group favoritism of their constituents. They argue that being an atheist is superior than being religious and lay out specific instructions as to how to negate atheist stigma and further an emerging atheist movement. The major script coming from this groups is come out and comparisons to the gay movement are prominent. They argue that the movement has been seeing increasing success and, as more atheists come out, more success will come. Under the tab "Coming Out" on their website, readers are immediately introduced to the association between atheist rights and gay rights while being encouraged to make themselves known, setting up the Christian Right as the out-group and antagonist.

"There is another closet which is hiding a different minority: atheists. Many of us, like many gays of previous decades, hide in the shadows due to fear of hostility and aversion to confrontations. But we can't stay in the closet any longer. The Christian Right, in their never-ending quest to make everyone Christian, has unleashed an unparalleled slew of efforts aimed at Christianizing the country."

"You're one of 25 million freethinkers in this country who will not follow blindly and who feel free to demand proof, or at least logically sound theory. Welcome. Your first responsibility (to you, not to us) is to make yourself known, to friends, family, other atheists, and your congresspeople. Come meet with us and get some foundation. We can help make this episode in your life much easier than it would be alone. Be a 
proud, open, honest atheist, not another closeted victim of the Christian Right."

These quotes not only illustrate the group's use of the coming out metaphor, they also show the way they set up religion, especially Christianity, as their antagonist. The second quote is a good example of how they are showing readers that their action will make a difference. By pointing out that there are 25 million other freethinkers, closeted atheists are more likely to feel that they are joining a successful and powerful movement.

Further down the "Coming Out" page on their website, the group appeals to closeted atheists and implies that being a closeted atheist is a form of oppression, framing the stigma of atheists as a civil rights issues.

"The wall of separation between church and state is sinking in the mud in places; we all need to get our hands dirty. If we don't, the mess wins...the cause of civil rights for non-believers is not dear to the hearts of everyone."

"How do you feel about hiding? Don't you feel that you're being oppressed for no reason? Do you feel like a second-class citizen, or that your acquaintances think atheism is something of which to be ashamed? The fact is, that there is nothing shameful about atheism. Rather, it should be viewed as a major accomplishment."

The first quote is a great example of how the American Atheists are encouraging other atheists to take action. Also, their use of "we all" and "if we don't" shows the collective identity rhetoric common in this groups' content. Finally, the first quote is an example of a more minor script being dispensed by this group, that of the need for separation of church and state. This is a major script of the movement overall and the American Atheists are known for fighting for this separation in court. Their website offers a list of lawsuits they have been and are currently engaged in, including a suit that asks that a cross be taken down from a public water tower and a suit against a Florida sheriff for 
holding a prayer rally. While some of their lawsuits involve discrimination against individual atheists, a majority are like the ones described above, fighting against the hegemony of symbolic civil religion in America.

The second quote illustrates the group's appeal to in-group favoritism as well as to some of the feelings held by closeted atheists. The connection between closeted atheism and oppression is similar to claims made by the gay movement. Finally, the last two sentences are a perfect example of the ways this group unabashedly sets up non-belief as superior to belief. Their website and publications are full of negative stereotyping of believers and positive stereotyping of non-believers. These next two quotes illustrate ingroup favoritism.

"It is a humbling and awesome responsibility to be chosen to represent people such as you who have strength of character to reject an epidemic of cultural mythology in favor of a life of reason" (Website, group president).

"We're independent thinkers, we question authority, and we take responsibility for our actions here on earth. We're statistically better educated, less criminal, and a little better-off than the rest of the country. Most importantly, though, atheists are reasonable - we at least endeavor to do what's right because it makes sense" (April issue, pg. 4).

Conversely, these next quotes illustrate the negative stereotyping of those who are believers.

"Having 'faith' has forever been presented as being something good and virtuous; but it is not a positive attribute, and nothing to be proud of. It equates to being merely gullible, superstitious, unquestioning" (April issue, pg. 15).

"You must be blind, stupid, or crazy to worship this god" (January/February issue, pg. 30).

However, the editor of the magazine is sure to emphasize that while humor and criticism are important aspects of the publication, “the magazine isn't a platform for ridicule. We 
will enjoy ourselves, but we also want to maintain a respectful relationship with our opposition" (March issue, pg. 7). Instead, the group emphasizes tolerance and one writer even discusses how they are willing to "coexist" with everyone, though they were sure to throw in a few jabs at believers.

"I can happily work within a group that welcomes any and all peaceful people to come and enjoy each others company, as humans, no matter how crazy, disillusioned, irrational, stubborn, morally inconsistent, unscientific, damned, doomed or just plain goofy we may find each other. So yes, please, by all means, let's coexist" (July/August issue, pg. 17).

Along these lines, the group makes the argument that non-believers need to stop worrying about labels and start uniting under common labels. They argue that the religious have the power that they do because they all unite under one label and the variation in labels among non-believers is seen by the group as divisive and hindering the success of the atheist movement. They even argue that "new atheism" is simply a term coined by their opponents to further divide non-believers.

"Don't worry about precision in your labels. If you ask a Methodist, a Lutheran, or Catholic what religion they are, they will likely all answer Christian. Now compare this to what you would get if you asked an Agnostic, a Secular Humanist, and a Secular Jew. None of them would answer Atheist. This needs to stop. We have to concentrate on what binds us...These arguments are worthless and counter-productive, as they could and do lead to animosity within the movement (this is a part of their plan, and this is why THEY coined the term 'New Atheist' to further divide us). 'Atheist' and 'Secular' are broad all-encompassing terms that should be used by everyone in the movement."

Another major strategy being used by this group is the use of billboards to disseminate their message of coming out as well as their critiques of organized religion. A major board for the 2012 campaign reads, "Tell your family you don't believe in god...they might just agree," with the text below it encouraging atheists 
to come out, as it will inspire others to do the same. Following strategies used in the gay movement, they encourage readers to literally "wear their atheism on their sleeve," using t-shirts and bumper stickers to alert others of their beliefs. Just in case you do not own any atheist paraphernalia, these products can be purchased from their website.

"Start wearing a suitable 'Your Friendly Atheist Neighbor' t-shirt. If you really are friendly, the other side might see you as someone to respectfully disagree with, not as a demon to send to hell as expeditiously as possible. That would be progress indeed" (June issue, pg. 9).

An important caveat to their strategies is that the group emphasizes that they are not attempting to convert believers, but simply trying to raise awareness of atheism and encourage closeted atheists and liberal believers to come out and support the atheist movement. One writer argued that atheists do not need to proselytize, as atheism should happen naturally for those who honestly consider it. This illustrates their lack of emphasis on redistributive politics that would call for converting others to their cause and completely transforming society. Instead, they emphasize affirming atheist identity so that atheists become a respected group in society.

"There is no effort here to convert theists into atheists, but there IS an attempt to get the church pew atheists to consider what they are doing. If they look at our billboard and see four myths, including Jesus, then why are they going to church and donating money" (Website).

"Atheism does not depend on being passed through families or communities. It is important for us to make known that it is good to be godless and that Atheists are everywhere, in order to end the isolation so many of us experience. But we don't need to knock on doors or call people at dinnertime to spread Atheism. Atheism can and does occur naturally to people who perceive that the real world is all there is and that tales of the supernatural are bunk." 
Finally, the American Atheists give their readers scripts detailing why they should come out and how that action will make a difference. Again, the emphasis is not on societal transformation, but instead on the empowerment of atheists. Note the use of a capital A when referring to atheists, subtly appealing to readers' potential in-group favoritism.

"Closeted Atheists look for more Atheists and find them. With company, closeted Atheists become more confident, more educated, and more brazen. That confidence leads to more Atheists coming out. Once Atheism is more visible, that results in decreased ignorance among believers, which also decreases bigotry. Less bigotry leads to an improved reputation of and treatment of Atheists, which ultimately causes more Atheists to feel empowered" (Website).

Further, the group makes many assertions that the atheist movement is succeeding and will see more success as more atheists come out. They argue that even though they are seeing success, they are still in constant battle with organized religion and thus atheists need to continue to take action and make themselves known.

"Do not think we have a smooth ride ahead of us. Religion will not give up its money and power without a fight. The momentum is on our side, but this pendulum will swing back. We must be prepared for a backlash...Atheism is not a fad, it's a trend, and it is going to continue" (Jan/Feb issue, pp. 12).

"If you are still in the closet, now is the time to come out. We must not coast just because we are riding downhill for the time being - we must pedal faster to increase our momentum as much as possible. This is done by being a vocal and proud atheist, and perhaps being an atheist activist. Read, learn, and speak about atheism as much as possible, and don't be afraid of ridiculing mythology (or calling religion mythology). Call the emperor naked - he is" (Website).

The above quotes are representative of the overall rhetoric found within American Atheist publications. With an emphasis on coming out, this group asserts that the atheist movement has gained momentum but could easily lose it to their religious opponents if 
they take this momentum for granted. Through appeals to in-group favoritism and analogies to the gay movement, the American Atheists offer fairly explicit scripts for action that mirror identity politics of previous movements.

\section{Freedom From Religion Foundation - Complain}

Acting as somewhat of an ACLU for atheists, this foundation's primary objective is acting on church/state violations in any way possible, whether it be through legal action, complaint letters, or protesting. They offer fewer explicit movement scripts than found in the American Atheist, and a majority of their publication and website are devoted to hard news stories about their legal action. Any allusions to an atheist movement or atheism as a collective identity are typically found in quotes from outside

sources. While they see coming out as important, and even dedicate their billboard campaign to this cause, they focus on educating readers about current church/state issues and what the foundation is doing to address them.

Like the American Atheists, they have a billboard campaign, which you are linked to when choosing their website link "Come out of the Closet!" FFRF billboards differ from American Atheist billboards in that they have pictures of actual atheists affirming their atheist identity. Colorful signs with pictures of men and women of all ages read "I can be good without God," "People of logic don't belong in the minority," and "This is what a secular family looks like." However, the overall message is similar to the American Atheist billboards; atheists are a stigmatized group in need of recognition and respect. Under the coming out section on their website is a statement that mirrors American Atheists scripts. 
"This is your chance to proclaim you're a freethinker and why. It's working for the gay rights movement. Now it's time for atheists and agnostics to come out of our closet. Many faces make Enlightenment work."

However, aside from the billboard campaign, coming out is not a major script being dispensed by FFRF. While they encourage atheists to advertise their stance through t-shirts and bumper stickers similar to the American Atheists, they do not use the coming out metaphor nearly as much to do so. When the group references an atheist community or atheist stigma, it puts less of an emphasis on nonbelief as a collective identity.

"In part because atheists are, according to the polls, the most-hated group in America, many atheists simply keep their nonreligious positions to themselves. I understand how much easier this approach makes one's dayto-day life, but I believe that silence further alienates young nonbelievers. It's important for nonbelievers to be open about their feelings" (Sept. issue, pp. 13).

"Don't let religionists win by default! The Foundation often receives mail from a lone freethinker claiming to be the 'only freethinker in Montana,' the 'only atheist in Utah,' or the 'only agnostic in my hometown.' Many freethinkers feel isolated because other freethinkers don't speak up. Let sympathetic friends and family know there is a group representing freethought and working for state/church separation. If you enjoy really advertising your views, the Foundation has produced bumperstickers, nontracts, buttons, solstice cards, T-shirts, and sweatshirts with educational freethought messages" (Website).

The above quotes are devoid of any use of the coming out metaphor or the use of "we" or "us" to denote a collective identity. Also, note the use of "freethinkers" and "nonbelievers" as opposed to "atheists" to discuss group members. FFRF is clearly advocating for the rights of all nonbelievers, and are not as concerned with affirming atheist identity specifically. Further, it takes more reading between the lines to get any direct movement scripts from this group. The majority of the website and magazine are devoted to hard news stories, with examples of identity politics being relegated to 
sections like "Meet a Member" or in essays by college students. In the "Meet a Member" section, members are asked questions like "What is the best way to promote freethought" in which one member responded with,

"By complaining about religious violations in local schools and government, voting in elections and writing letters and op-ed pieces for the local newspaper" (September issue, pg. 2).

The above quote represents the major script that FFRF does offer, the script that nonbelievers should continuously complain about church/state violations. Instead of emphasizing coming out, FFRF emphasizes the need for atheists to stop church/state violations and even have a section in Freethought Today called "It Pays to Complain" where they list numerous news blurbs detailing legislation and other complaints they have made on behalf of the separation of church and state. On their website under their "Take Action" heading reads,

"Freedom depends on freethinkers. The Freedom From Religion Foundation runs an online Action Alert, so that members may flex collective muscle over state/church problems, or react quickly when public officials take potshots at unbelievers. The Foundation also offers ideas for individual action, so you may take action, right now! And we sponsor an ongoing billboard and bus sign campaign to make freethought visible in your area. Get involved."

In addition, when co-founder Dan Barker is asked what he is asking his members to do, he answers with, "We are asking them to write letters of complaint" (April issue, pg 5.) In some ways, the foundation is asking atheists to come out; to complain about church/state violations, one has to assert their rights as an atheist. Someone who is completely "in the closet" is not likely to complain about prayer in schools or crosses in public places.

However, the language used is different than the language of American Atheists, which is more explicitly identity focused. Further, the coming out encouraged by this group is not 
the type of coming out that we see being encouraged by the American Atheists, which is more of a public proclamation. Thus, FFRF and American Atheists are employing two differing strategies in their approach to identity politics, with American Atheists leaning heavily on criticizing the norm of religious identification and affirming atheist identity and FFRF focusing on educating the public about atheist rights and engaging in legal action.

Despite this difference, the critique and ridicule of religion are also present throughout FFRF's site and publication, affirming nonbelievers as the in-group and believers as the out-group. They devote two entire pages to their "Black Collar Crime Blotter," a section that lists any recent crimes committed by, lawsuits filed against, and resignations of religious leaders. In addition, they always dedicate a portion of each issue to two sections that never fail to put religious identifiers in a negative light, "Crank Mail" and "Overheard." The first section is a collection of hate mail the foundation received throughout the month. Without correcting for spelling, grammar, or profanity, crank mail highlights hateful and disturbing threats and accusations from those who oppose nonbelief. One reads, "May your children choke on fish bones right in front of you" (June/July issue, pg. 7) and another, "Atheists, you are enemies of god and are going to be annihilated. Repent and turn to god or be destroyed" (Sept issue pg. 7). These are mild examples, and the profanity and violence coming from this section is likely to disturb readers, which is obviously the goal, and further polarizes nonbelievers from believers.

The foundation's literature is also littered with quotes from famous atheists, intellectuals and celebrities that promote nonbelief and/or separation of church and state, for example in their "Overheard" sections. These quotes are juxtaposed with quotes from 
religious figures or religiously-oriented politicians, implying that the former are legitimate and the latter are wrong or laughable. These sections explicitly place nonbelief as superior to belief and are an example of the group promoting difference rather than sameness. Below is an example of quotes found in these sections, one from each side.

“Today I quit being a Christian. I'm out...it's simply impossible for me to belong to this quarrelsome, hostile, disputatious and deservedly infamous group" (Sept. issue, pg 4, Author Anne Rice, online announcement on Facebook)

"Tonight, we pray for that courage. We pray for the people of the gulf. And we pray that a hand may guide us through the storm toward a brighter day. Thank you, God bless you, and may God bless the United States of America." (June/July issue, pg. 20, President Barack Obama, Oval Office speech).

The use of celebrities, intellectuals, and in this case the president of the United States, to illustrate in-group favoritism is likely an effective tactic. It is one thing to read about a stranger converting to atheism, but it is likely more powerful to hear it coming from a celebrity that has a tangible existence for the reader. In addition, the way these quotes frame comments from those who are religious is also likely to be effective, as they often come from powerful figures in politics who, again, have a tangible existence for the reader. This has the potential to make the reader feel connected to the "freethinking" ingroup in a powerful way.

Overall, the Freedom From Religion Foundation offers fewer movement scripts than the American Atheists, however the overall tone and purpose are similar for both. With a focus on engaging in legal action and filing complaints, the FFRF encourages its members and readers to be vocal about their beliefs and follow in their complaining footsteps. However, the language used by the groups differ, and the American Atheists 
are more prone to offer collective action scripts where the FFRF tends to focus on individual action.

\section{New Atheists - Criticize}

"The fact that nearly half of the American population apparently believe [the end of the world is coming and it is a good thing], purely on the basis of religious dogma, should be considered a moral and intellectual emergency" (Harris 2005: Xii).

"As I write these words, and as you read them, people of faith are in their different ways planning your and my destruction, and the destruction of all the hard-won human attainments that I have touched upon. Religion poisons everything” (Hitchens 2007: 13).

With statements like the ones above, the New Atheists begin their books with urgent and radical language to describe the state of religious belief in American society today. While differing slightly in approach, all of the New Atheist authors offer similar scripts in their bestselling books which openly criticize organized religion. Harris, Hitchens, and Dawkins published their books after the September 11 attacks, and all focus on highlighting the dangerous role religion can play in society. Unlike their atheist counterparts in the national groups, these authors emphasize that religion is harmful and does not deserve the respected place it holds in American society. While the national groups often poke fun at religion and criticize its influence in society, they are always sure to qualify these statements with the need for religious tolerance. In contrast, the New Atheists reject this tolerance, arguing that it "is one of the principal forces driving us toward the abyss" (Harris 2004: 15). Their tones are caustic as they relentlessly attack negative aspects of religion, urging readers to confront people of faith. While they 
occasionally address the need for atheists to come out, they offer little in the way of movement scripts. Further, while they give readers sufficient ammunition if confronted by religious arguments, they rarely address atheism as a collective identity.

The most prominent theme among all three of these works is the argument that religion should not hold the respected place it has in American society. These authors spend hundreds of pages outlining historical atrocities committed in the name of religion, including war, sexual abuse, and child indoctrination. Further, they relentlessly ridicule people of faith for their beliefs and argue that these beliefs are the reason for many problems in American society. Their overall argument is that faith is inferior to science and the goal is the eradication of religion entirely.

"A widespread assumption, which nearly everybody in our society accepts - the non-religious included - is that religious faith is especially vulnerable to offense and should be protected by an abnormally thick wall of respect, in a different class from the respect that any human being should pay to any other" (Dawkins 2006: 42).

"Our fear of provoking religious hatred has rendered us unwilling to criticize ideas that are increasingly maladaptive and patently ridiculous" (Harris 2005: 80).

"In a vast and complicated discussion where we know more and more about less and less, yet can still hope for some enlightenment as we proceed, one faction - itself composed of mutually warring factions - has the sheer arrogance to tell us that we already have all the essential information we need. Such stupidity, combined with such pride, should be enough on its own to exclude 'belief' from the debate. The person who is certain, and who claims divine warrant for his certainty, belongs now to the infancy of our species. It may be a long farewell, but it has begun and, like all farewells, should not be protracted" (Hitchens 2007: 10).

These quotes begin to illustrate the intensity with which these authors approach religious criticism. Phrases like "patently ridiculous" and "sheer arrogance" are prolific throughout all of these works and the authors do not qualify these statements with a need for 
tolerance. Further, these authors state that they do not find their tone out of line, and

Dawkins even addresses the criticisms that he is too strident, arguing

"The strongest language to be found in the The God Delusion is tame and measured by comparison. If it sounds intemperate, it is only because of the weird convention, almost universally accepted that religious faith is uniquely privileged: above and beyond criticism. Insulting a restaurant might seem trivial compared to insulting god. But restaurateurs and chefs really exist and they have feelings to be hurt, whereas blasphemy, as the witty bumper sticker puts it, is a victimless crime" (Dawkins 2006: 16).

These authors are just as harsh on their fellow nonbelievers in some regards. For example, they berate nonbelievers who find benefits in religion almost as harshly as they do those who hold those beliefs. Addressing atheists who have emailed him arguing that religion has its positive aspects and complaining about the strident tone of his work, Dawkins states,

"A baffling large number of intellectuals 'believe in belief' even though they lack religious belief themselves. These vicarious second-order believers are often more zealous than the real thing, their zeal pumped up by ingratiating broad-mindedness: 'Alas, I can't share your faith but I respect and sympathize with it.' 'I'm an atheist, BUT...' The sequel is nearly always unhelpful, nihilistic or - worse - suffused with a sort of exultant negativity" (Dawkins 2006: 13).

The above quote illustrates the group boundaries drawn by the authors and the way they treat atheists who fail to be loyal to their ideas. They, unlike the national groups discussed earlier, do not see nonbelief as all-inclusive and Dawkins even devotes a section to the "Poverty of Agnosticism" in which he criticizes agnostics for fence-sitting. He argues that atheists do not have faith, thus no atheist is absolutely positive that god does not exist, however, to call yourself an agnostic is meaningless stating, "I am agnostic to the extent that I am agnostic about fairies at the bottom of the garden" (Pg. 74). Further, these authors argue against many nonbelievers' claims that moderate religion has benefits and 
that it is extreme religion that needs eradicating. These authors are all very clear on their stance against this argument and argue that moderate religion enables extremism.

"My point in this section is that even mild and moderate religion helps to provide the climate of faith in which extremism naturally flourishes" (Dawkins 2006: 342).

"Religious moderates are themselves the bearers of a terrible dogma: they imagine that the path to peace will be paved once each of us has learned to respect unjustified beliefs of others. I hope to show that the very ideal of religious tolerance - born of the notion that every human being should be free to believe whatever he wants about God - is one of the principal forces driving us toward the abyss" (Harris 2005: 14).

Despite their focus on the negatives of religion, the New Atheists do address

atheism as a collective identity or as a movement in limited portions of their work.

Overall, they argue that atheists are more numerous than people think but that they are failing to successfully organize. However, these discussions are not centered on the idea of coming out or affirming atheist identity, instead they focus on the need for atheists to question and criticize all aspects of religion, as this will only hasten the demise of religion that they strongly advocate and explicitly argue is inevitable.

"The isolation of American atheists is an illusion, assiduously cultivated by prejudice. Atheists in America are more numerous than most people realize. American atheists far outnumber religious Jews, yet the Jewish lobby is notoriously one of the most formidably influential in Washington. What might American atheists achieve if they organize themselves properly?" (Dawkins 2006: 65).

"According to a report in the Wall Street Journal, my book is selling particularly well in the Bible Belt, on a know thine enemy basis. And I get encouraging letters from atheists in foxholes in Iraq and Afghanistan, as well as from people who feel that they are at last emerging from some kind of closet. One day a decent candidate for high office will say that he is not a person of faith, and the sky will not fall" (Hitchens 2007: 293).

"I would be the first to admit that the prospects for eradicating religion in our time do not seem good. Still, the same could have been said about 
efforts to abolish slavery at the end of the eighteenth century" (Harris 2006: 87).

The above quotes differ in purpose, but the overall message is that atheists are numerous and the eradication of religion is an achievable goal, though Dawkins implies that American atheists have failed to organize successfully. Harris admits to the difficulty of the task, though Hitchens is increasingly encouraged by the path he feels atheism is on, even alluding to the closet metaphor to do so, a script not prominent in these works. This metaphor is mostly found in Dawkins' work, for example he states,

"The reason so many people don't notice atheists is that many of us are reluctant to 'come out'. My dream is that this book may help people to come out. Exactly as in the case of the gay movement, the more people come out, the easier it will be for others to join them. There may be a critical mass for the initiation of a chain reaction" (Pg. 27).

“'The-Brights.net' (an American initiative to re-brand atheists as 'Brights' in the same way as homosexuals successfully re-branded themselves as 'gays')...I signed up to the Brights, partly because I was genuinely curious whether such a word could be memetically engineered into the language. The Brights campaign got off to a shaky start when it was furiously denounced by some atheists, petrified of being branded 'arrogant'. The Gay Pride movement, fortunately, suffers from no such false modesty, which may be why it succeeded" (Pg. 380).

Dawkins' statement that gay pride was successful precisely because they were prideful is an interesting point. Like the national groups, he argues that the more atheists come out, the more likely they will see successes similar to the gay movement. However, unlike the national groups, he is arguing that atheists should not only come out, but come out forcefully and even with arrogance if needed. Again, this illustrates the intense in-group favoritism being fostered by these authors as well as their intense disregard for religious tolerance. However, Hitchens is not fully on board with the Brights argument. "My own annoyance at Dawkins and Dennett for their cringe-making 
proposal that atheists should conceitedly nominate themselves to be called 'brights' is a part of a continuous argument" (Pg. 4).

Thus, these three authors do not agree in every aspect, but the tone and purpose of their works are similar. They argue that religion should not longer be respected and that atheists need to do more to change the way Americans treat religion, though they do not offer much in the way of action in regards to how atheists should go about eradicating religion, or better yet what they should replace it with. With a few allusions to coming out and the growing number of atheists in America, these authors do not go further to promote an atheist identity movement and simply encourage intense criticism of religion. For the most part, the purpose of these works is to detail the arguments for and against the existence of god, outline different religions and the errors found within them, and stridently criticize anyone who not only holds a supernatural belief, but anyone who finds a positive in holding a supernatural belief.

\section{Conclusion}

The purpose of the analysis of atheist group literature and popular atheist authors was to get a sense of the ways these "leaders" of the atheist movement are dispensing scripts to potential movement members. As Benford and Hunt (1992) argue, movement leaders "define the scene, identify actors, and outline expected behavior" (P. 87). Thus, the scripts being offered by groups and authors who are seen as leaders of the atheist movement are key in understanding the scripts that individual atheists are exposed to. Understanding whether or not these scripts resonate with individual atheists will lead to a better understanding of the successes and failures of attempts at atheist identity politics. 
The analysis of atheist groups and authors revealed differing movement scripts, though the overall message is clear: atheists are stigmatized and they need to be more vocal in the public sphere in order to negate that stigma and further secular thought and practice. Comparisons to the gay movement are prevalent and the use of the coming out metaphor to emphasize a need for atheists to affirm their atheist identity was a popular script. The groups advocated for promoting atheism through t-shirts, billboards, bumperstickers, and letters to congressmen and the authors advocated for promoting atheism through harsh critique and questioning of religious practices. While the groups and authors differ in their opinions on religious tolerance, all of the content was full of religious criticism that placed non-belief as superior to belief. This illustrates that the identity they are promoting is one that is directly built off of the rejection and opposition to the religious. Finally, movement language is found throughout the literature, with the groups and authors implying that the atheist movement not only exists but that it is seeing significant success. The following chapter details interviews with individual atheists in Portland, Oregon regarding their opinions of these groups/authors and their strategies as well as the ways that respondents identify with a collective atheist identity. 


\section{CHAPTER 5: INTERVIEW FINDINGS}

While atheist leaders and authors are dispensing numerous scripts, using identity politics and encouraging atheist activism, these scripts resonate with individual atheists in different ways. After discussing these authors and their strategies in-depth with my participants, as well as branching off into discussions of atheism as an identity, a movement, and a defensible worldview, I attempt to understand the way my sample of 15 atheists in Portland understand their atheism and atheism as a social movement.

To start, not all of the respondents agree that there is an atheist movement and they express differing opinions regarding the strategies being used by the movement as well as the success of the movement activity they see. While they agree that the politicization of religion is negative and they support the idea of a more secular nation, few of them participate in activism and most disagreed that atheism is an identity in need of affirmation. However, all of the respondents have encountered at least one of the movement leaders or strategies discussed in the previous section and this section will detail their reactions. I will start by discussing the religious background of my participants, how they came to atheism, and what that atheism means for them. I will also discuss how they develop their atheist identity through reading literature and attending groups. Then, with an understanding of respondent's backgrounds and identity development, I will transition into a discussion of the ways they are reacting to atheist movement strategies, if and in what ways they are participating in activism, and what they would like to see from an atheist movement. While detailing respondent reactions to movement scripts, I will discuss how certain backgrounds and ways of coming to atheism affect respondents' desire to participate in activism and their opinions of movement 
strategies.

\section{Becoming Atheist}

The ways my respondents made the transition from believer to atheist, or from simply uninterested to atheist, mirrors findings from Smith's (2011) study on atheist identity. Smith argued that there are four steps to becoming an atheist: encountering theism, questioning theism, rejecting theism and finally "coming out" as an atheist. My participants closely followed the first three steps, though the fourth is up for debate and my respondents had differing opinions on the coming out process. First, out of the fifteen participants, only five came from a strong religious background, however all of the participants had attended church at some point in their life and none were "raised atheist." Thus, mirroring Smith's first step, all of my respondent's had at some point encountered theism. Second, they began to question this theism. This generally came early for my participants and some even discussed having doubts as early as age 7 , though it took others until their mid-30s. All of my participants completed at least some college, and a majority found it to be a breeding ground for secular ideas. College was where many who were doubting their religion or just simply not defining themselves as anything began to look more closely at their beliefs.

"Before I went to college, it wasn't really something I defined. I was just like, well no, I don't believe. I probably took the atheist label when it became an issue in school. Because you have a whole bunch of cultures meshing together and all of the sudden people are talking and you're all the same age. And they were like, oh, so you're an atheist. And I had to go look up the term and I'm like, oh, ok, it's nonbelief, I can roll with that." 
"And in school when I went to college the atmosphere was very secular. I think I slowly dropped my belief and was kind of not really sure."

The first quote comes from a woman who had grown up as a secular Jew and thus never seriously identified as a theist, but being in the college atmosphere forced her to define herself for others. The second quote is typical of those who had grown up with a believing background and found college to be a place where those beliefs were challenged and their doubts grew stronger. For both groups, college was a place where they seriously considered their religious identity and began to put a label on it. The third step, rejecting theism, came about in different ways, though there were definite similarities. While some took on the atheist label due to the secular environment of college, echoing Hout and Fisher (2002), for four respondents the politicization of religion and 9/11 were the catalysts that led them to take on the atheist label. They discussed how the infamous terrorist attacks showed them the evils that religion could enable and pushed them to dissociate from it.

"For the longest time I was just sort of like, a nonbeliever who didn't really talk about it, didn't really think religion was a problem in society or dangerous. People can believe whatever they want. And then after 9/11, it was sort like a wakeup call as far as what religion does in society. And then I started being really concerned about the role of religion in politics and what not."

"And then 9/11 happened. At that point, I had decided I just don't believe in religion, but I didn't take it beyond that. I didn't read books or join groups. But when 9/11 happened, shortly after that happened a lot of people became deeply religious, including my step-mom. And then there became this groundswell of support for evangelical Christianity and George Bush and I thought that was extremely bad and I was very unhappy about it."

The final major catalyst respondents pointed to as pushing them to reject theism was being exposed to a book or a movie they saw on the subject. A surprising five 
respondents pointed to the New Atheist authors as their reason for taking on the atheist label, though some discussed lesser known atheist authors and one woman discussed how the movie Zeitgeist ${ }^{13}$ was what caused her to go from doubting to atheist. She said the movie showed her "what I had already been thinking but was too afraid to put together." They discussed how these different forms of media affirmed their doubts and gave them a language and way of thinking about their beliefs that they did not have before.

"And then I came across a book called A Letter to a Christian Nation by Sam Harris and I thought, this is exactly right! That motivated me. And I thought. It's completely true, I'm totally an atheist."

"And I just had these doubts. I just said, well what in the heck do I believe, I had no idea what I believed. And I picked up a copy of Richard Dawkins, The God Delusion. This was a big moment for me because it's when I found out there were other people with doubts like myself and I guess that's pretty much when I realized, yeah, I'm an atheist."

"I do remember feeling pretty well transformed by [Why I am Not a Christian], like, oh, I feel like I can articulate my thoughts a lot better. What is that process of learning, what is the language, how do you respond when somebody says this particular idea is real when deep down is all you have is a feeling that that can't be true. So, Bertrand Russell and all of these other people give you some thinking tools and a language to use."

While Smith (2011) argued that "coming out" as an atheist is a crucial final step in forming an atheist identity, as it also allows for atheist beliefs to move beyond merely a label to a salient aspect of their identity, this was not as strongly mirrored in my interviews. While all of the respondents see coming out as a positive strategy, and many brought up the term before I did, very few are completely open about their atheist identity to others. Many avoid conversations about their beliefs and few defend their atheism in public. For the three respondents that said their beliefs were a common topic of

13 A 2007 documentary that dedicates a large portion of its time to asserting that Christianity is a myth and is based on numerous older religions. 
discussion and did defend their beliefs to others, two noted that they were doing so less now, either because they were experiencing negative reactions or because it was just not something they cared about as much anymore. The following quote illustrates how a majority of respondents felt when asked if they thought atheists should come out.

"I definitely think atheists should come out. I think a lot of atheists don't come out because they don't know how many of us there are. And the more out we are, the more questions that are going to be answered, and the less fear that will be attached to it, and the more, I think, a lot of people will realize that they're atheist too."

However, when asked if they talked about or defended their beliefs in public, in other words, were they out themselves, responses generally included "it doesn't really come up" or "it is just not something that is relevant." While all of my participants had told their close friends and family about their beliefs, it was not a topic they brought to the workplace or social gatherings.

"I try to disengage now, or I think I do, I certainly talk less about it now. I think I'm just getting beaten down over years of having these kinds of conversations with people that don't go anywhere. It's hard to win. My conversion rate is extremely low."

"I really have not had that. Maybe once or twice, very briefly. I don't provoke, I'll put it that way. And since so many people I know could care less about it, I usually don't get the opportunity to do it."

"Not really. But just in general, even with my friends who are Catholic, friends who are Christian, you know, it really doesn't come up when we are barbequing, we really don't discuss it much."

"You don't want to blatantly offend your neighbors, you know, you might need a cup of milk. Being atheist gives you the unique position to lie about stuff without impunity because, you know, I can tell a Protestant person I'm Protestant if it makes sense, cause, I don't care."

This rejection of "outness" found in my sample stems from a number of factors, one being that they feared a negative reaction. Some respondents pointed to a fear of losing 
friends, families, or jobs, but a more common implied response was that they simply did not see a need for it. All of my respondents discussed how their friend groups included both religious and non-religious friends and that they are able to intermingle with their religious friends without any problems. Three respondents even discussed how they had been married to or were willing to date or marry someone who was not an atheist. Further, none of my respondents had been shunned from their religious families or experienced any real discrimination based on their atheism, thus coming out was not seen as a priority. Thus, a major reason respondents are disengaging from being an "out" atheist is because atheism is merely a label for them, and not an identity in need of defending.

\section{Atheism as a Label, Not an Identity}

Researchers argue that atheism can indeed be a salient identity for people (Baggini 2003, Cimino and Smith 2007, Anisman et.al 2010), however this was not true for a majority of my participants. When discussing with participants what their atheism means to them, many discussed how it was simply a stance and not a sufficient label to define their worldview or identity. For five respondents, secular humanism, a secular philosophy that rejects religious dogma, was a way to fill in the gaps that their atheist label left open.

"I'm still groping for what I am. I would definitely say that atheism is not a sufficient philosophy. I don't think it really has very much explanatory power. See I don't believe that atheism in and of itself, uh, I think atheism is nothing. It's very limited. It's like, what you add on to it. It's a personal thing."

"I've been kind of exploring humanism as a replacement for having some 
sort of ethical worldview, and it seems like humanism, from what I've read, I have a couple books on, it seems like it makes the most sense.

"Well, atheism is just a choice. It's a decision that you don't believe in the existence of god. But still the questions remains, how now ought one live their life? What kind of ethical life are you going to live? For me, it's that of a secular humanist."

One possible reason that my participants do not see atheism as a salient identity is because they do not see representations of it in the real world. Brewer and Silver (2000) argue that when someone joins a group, they attempt to mold their self-perceptions and behaviors to match that of the prototypical representation of those behaviors and attitudes that define the in-group's distinctive identity. However, respondents discussed how it was difficult to know how to develop an atheist identity or to know what an atheist identity was because there are no "codified rules for atheists;" there is no prototype to replicate.

"And I think, really, beyond the dictionary definition of it, atheism has not collected any other attributes and images to itself. Unlike religion which has so many trappings. When you say Christian, there's so many things that are attached to that word. Whereas atheist, I think today, one could say things about atheists, but it is not codified anywhere. Are atheists good, are atheists bad? There is no so-called authority to dispute any of that. There is no, like, chapter of atheism, or things like that."

Further, over half of my participants discussed how the lack of rules or codes to live by is precisely what they like most about atheism. For both those who grew up religious and those who did not, being told what and how to believe was something they were trying to get away from.

"[Secular humanists] have a set of principles. I don't think that they force to you follow them, it's just I don't want to be...my principles right now are just so hard fought, I want ownership of them. And to give them away to any other organization doesn't sit well with me."

"I don't think I need to have a sort of code to live by...other than the codes that are just passed down in regular old social relations, like in your 
family."

Conversely, especially for those who grew up in a strong religious family, they found this openness to interpretation insufficient for identity formation and were in search for a way to supplement their atheism, such as with secular humanism in the previous examples.

"Frankly, I'm so new to this thing, I feel that just saying I'm an atheist, it's probably not sufficient to be a complete human being. You should have a sense of social connection. A sense of what it is, what it means to be a good person. All of these things come with religion. It's embedded, it comes with the package. Whereas you cannot completely assume that with atheism."

Thus, whether or not respondents felt comfortable with the lack of codes and prototypes to model their behavior and beliefs after, they all implied that this was a major reason for the lack of salience their atheist label held for them. For those who were interested in developing their nonbelief identity further than their atheist label was taking them, atheist groups were the first step to understanding what being an atheist meant and how others were playing out the atheist role. Not surprisingly, those who were not as interested or concerned about their lack of nonbelief identity were less likely to attend or want to attend groups. These groups are called "meetups" and interested respondents generally found them through searching for atheist groups on the internet. These meetups are social gatherings where anyone, though it is mostly atheists, can come and have a coffee or a beer and simply socialize. When asked why they started going to groups, there were three major categories that answers fell into: meeting other atheists, learning more about atheism, and/or replacing the community they lost when they left religion.

"I initially joined to learn. I wanted to talk to other people about it and see in fact if other atheists didn't have horns growing out of their head."

"I originally, and to this day, joined the groups with the intention of 
identifying with other atheists. Identity is very important, especially if you moved away from a former identity. It was just to socialize and I realized I needed to have more of a secular community."

"I think I was looking generally for atheist resources. I wanted to see, what does an atheist look like? I had not met a single atheist. I was really wondering how secretive would they be. I was just curious."

As the above quotes illustrate, these respondents, while identifying as atheist themselves, had little to no contact with other atheists before going to one of these meetups, further illustrating the lack of atheist role representation in their lives. They were looking for a community and friends, but they were also looking to see how other atheists were presenting themselves in order to better understand how they should present themselves. This follows Ritchey's (2009) discussion of how these meetups are communities of practice in which groups of people who share a concern or a passion for something learn how to do it better as they interact regularly. Another major reason given for attending these meetups was that they are a safe place for throwing out ideas and seeing how others responded. As discussed earlier, most of my participants kept pretty quiet about their beliefs in public, and these groups were a place they felt safe enough to speak up.

"Well, I went to meet other atheists basically, I mean, because I didn't know any. And it was basically just a bitch session. Someone I could just let it all out, you know, you didn't have to censor yourself around people, they all felt the same way."

"And that was one of those rare instances where I could open up about who I was and have rational discussions about things. And they weren't always about atheism as they often are not."

Respondents who frequented these groups had both positive and negative things to say about how the groups fit their expectations. Some respondents discussed how these 
groups have begun to form a "secular community" that was capable of replacing the religious community that they left behind. They felt that, even if they did not go all the time, it was nice to know that there were groups out there promoting atheism.

"That's the one thing I missed about church, the community of it. In fact we have one person working on a list of what everybody does, so, if you need a plumber, is there one in our group? Which is kind of something churches do. And if something happens to a member then they have other members that can help. So that support group is letting people leave church because there is somewhere else to go."

However, other respondents made the argument that these groups were not enough to replace their religious communities, as they were based on intellectual discussions and lacked the emotional connections found in religious communities. Further, these groups were purely social and lacked the political agenda that some respondents were looking for.

"One of the ways it's lacking is there's a lot of debating and talk about religion, but there's not a lot of emotional connecting with people on a personal level, only intellectual for the most part. If you can't get to know someone, on all levels, you're never really going to have a real trust and relationship with that person. And because those type of relationships were never established, it never became a community, a family. A lot of it also was done online. And emails do not substitute for face to face."

"At this point, it is all social and intellectual. I wouldn't say it's that emotional. Or for that matter, it's not political. I know atheists are trying to do political things, but I don't think the community is involved. I think a few people up there are hiring lawyers and doing something, but I can't see the whole community being engaged. Like, I don't know what's going on and I go to these meetings."

"I don't know, most people just come up there once or twice and it's too infrequent. Once a month. And so, it's just not enough social interaction. Everybody's strangers, you know."

The above quotes bring to light numerous issues within the atheist groups. The first being that they lack the emotional connections that these respondents had in their 
religious community. This type of description came primarily from respondents who had strong religious backgrounds; group members who did not come from religious backgrounds tended to expect less from the groups and simply went to socialize. Closely related is the issue of these groups being primarily internet based. These groups only meet once a month and members stay in contact the rest of the month through Meetup.com and Facebook. The American Atheists hailed the internet as the hero of the movement, saying "To say that we've succeeded is an understatement, but we must give the real credit to the true hero of Atheism: The Internet." As technology has advanced, movements have increasingly been turning to the internet as a tool (Schroer 2008). While there are definite positives to this strategy, such as easy access and constant contact, some of my respondents feel that using the internet to substitute for face-to-face communication hinders community and relationship building among atheists.

The final point the above quotations illustrate is the lack of political organization found in the groups. As discussed earlier, engaging in activism was not a common reason for joining these groups, but it was noted by more than one participant as a negative aspect of what they found in the group. Further, two of the non-group members discussed how they were hesitant to join any groups because they did not feel there was enough activism involved and they were not interested in simply socializing. However, these comments came from respondents who had a strong atheist presence in their friends and family, and thus were not necessarily looking to just make more atheist friends.

"I already have friends who are atheist. My ex-wife is atheist, her family is atheist. I feel like I have a community of people where I can say what I want and it's not strange. I think I would probably want to do more than have...maybe something that was politically oriented in some way." 
The previous two sections detailed the ways that respondents came to atheism and what that label means for them. Overall, respondents do not see atheism as a salient identity for them, which is a major reason they are mostly quiet about it in public. While many of my respondents turned to group meetings to further develop the atheist aspect of their life, all but two generally leave group meetings feeling unfulfilled emotionally, socially, or politically. The following sections will discuss how this background information translates into movement knowledge and action. I will first discuss respondents' reactions to national groups and leaders attempts at identity politics. I will then discuss the ways that respondents' either do or do not use the scripts being offered to strategically deploy their atheist identity, why or why not, and what it would take for them to do more of it.

\section{Reactions to Movement Scripts}

The majority of my respondents pointed to the New Atheist authors as their primary source for atheist information, though at least five discussed how they more often used internet sites such as Reddit.com and YouTube. However, the three respondents who said they used YouTube said they used it to watch videos of the New Atheists in debates. Conversely, only one participant was familiar was the Freedom From Religion Foundation and its publication, and the rest had either never heard of this foundation or American Atheists, or were vaguely familiar that they existed but never looked into what they were about. The one respondent who was familiar with FFRF pointed to their legal action as what appealed to him. 
"I like that that group is taking action. When there's a school that's ramming religion down the kids throats, they'll sue. I'm hugely in support of that. I like the lawsuits that they file and the guest articles. And they also run articles about people who converted. So, those were always interesting, the personal stories."

However, another respondent attempted to describe why he was not drawn to this group. It had nothing to do with the content, he was just simply not interested in a print publication. He had already established his favorite sources for atheist information and was not open to adding FFRF or American Atheists to that list.

"I don't think people read that stuff. I really question whether a, especially a printed piece...I think people know exactly what they want, they go specifically to a place, and they get it. That's what I do. I know exactly what I want, I have my own RSS feeds, and it will take me all of two seconds to decide, I'm going to read this or I'm not, and I'm going to move on. And that's what happened on that site. Something about that doesn't appeal to me so I'm going to move on to something else."

This is an important finding because this kind of attitude towards the publications was not uncommon; respondents were just not interested. This has a huge effect on what scripts these respondents are being exposed to as well as who they see as representing them as an atheist.. It also speaks to the ways script dissemination strategies are forced to evolve with technological advances and changes in the ways people get their information. American Atheists and FFRF are desperately trying to get their message out to atheists, however their print publications are not competing with the internet or popular authors What is interesting, and will be discussed throughout this section, is that the scripts being offered by these national groups more closely mirror what my respondents want to get out of a movement. However, my respondents are not exposed to these scripts and instead gravitate to the New Atheists, who are not necessarily seen as "model atheists" by many of my participants. 
All of my respondents had heard of at least one of the New Atheists and all but two had read one or more of their books, watched them in Youtube debates, or read articles about them online. The first section of this chapter discussed how my respondents came to atheism, and at least five pointed to reading the New Atheist authors a major turning point in their thinking. Building on that, I asked respondents what it was they liked about these authors and what criticisms they had. Some respondents said they could not think of any criticisms and spoke about them with reverence.

"It disturbs me about Sam Harris is that I agree with him so much. I don't like to agree with somebody as much and it bothers me. But I've read just about everything that he's written, listened to about every debate. It's really kinda pathetic. And I can't really disagree much with what he said, and I don't really like that, but what do you do?"

"Like, everything [Dawkins] says I believe. He's so articulate, perfect. He expresses so many of the things I'd like to express."

"I have read Dawkins, Hitchens, Harris, I pretty much agree with them. I can't find anything that I disagree with."

Further, many of my respondents discussed how they identified with the authors for the merit of their arguments, but it was also the caustic tone which these authors are infamous that attracted them. Previous researchers have found that the strident tones of these authors are generally criticized by atheists (Foust 2009, Cimino and Smith 2011), however this sample of atheists were much more prone to admit to liking the tone of these works, even if they felt it went too far at times.

"Read End of Faith and liked it because it was unapologetic and really, really critical at a time when it was obvious that people should be critical, right, like right after $9 / 11$. So it was really refreshing to hear somebody to go on the offensive. Daniel Dennett seems more, I really sort of like the militant atheist style, and he seemed a bit nicer and I kind of like a real critical angle." 
"[Hitchens] is a bit caustic. And I like that, a little bit, kind of. He's sort of a militant atheist."

"Should we be accomodationists or is Dawkins and Harris' technique too hard or insulting? I know that the way many theists think of atheists is disturbing. And I know that some atheists can be dicks. But for me, the number one thing is intellectual honesty, and to be honest with you, I have never heard, especially Dawkins and Harris, anything that I thought was inappropriate".

I will discuss respondents' criticisms of these works shortly, but I wanted to point out an interesting theme that emerged from discussions about these authors. At least five of my respondents felt compelled to give me a run down of each author, detailing the angle they take, their background and who their favorite of the authors was. Further, two respondents used these authors as a way to tell me what kind of atheist they were. This is interesting as it illustrates the way respondents use these authors as representations of the prototypical atheist, which as I discussed earlier they felt was lacking in their life.

Respondents talked about these authors as if being versed in them was a requirement and had obviously discussed their strengths and weaknesses with others. When asked what atheist authors she was familiar with, one respondent said "Well, the usual, Richard Dawkins, Sam Harris, Christopher Hitchens." Her use of "the usual" is an example of the assumed familiarity she felt other atheists had with these authors. Below are further examples of how respondents talk about these authors.

"Well, at first I really liked Dawkins. At first I didn't like Sam Harris, but now I'm a huge Sam Harris fan. And he's probably one of my intellectual favorites. I didn't particularly care for Hitchens, although I like listening to him. Harris is a great debater. Dennett is a terrible debater but he's a great thinker. So, I like reading Dennett and Harris. I do like listening to Hitchens speak. Dawkins, I don't like to listen to him speak, I like his books." 
"There's a conference in Australia that I really want to go to next spring. Because, you know, Hitchens might die, and all four are going to be there. If he makes it to next year and he makes it down to Australia, I think that would be awesome to see all four of them there. That provides a sense of community."

"Each of the New Atheists have a little something different to bring to the table. I tend to identify as more of a Sam Harris/Dennett."

"See, I've been struggling with atheist definitions but I remember Dawkins was asked to grade himself on a scale of 1-7, and said he would be a 6 . Seven would be the absolute conviction that there is no god. I think, I would also like to put myself somewhere there."

The first quote is an example of the ways respondents would detail the differences they saw among the authors. The respondent discussed how he liked all of the authors, but liked to get information from them in different ways and for different reasons. The second quote is great because it shows how connected this respondent feels to these authors. Saying that it would be great to see all four of them together, this respondent definitely feels a sense of community through these authors. He also mentions the possible death of Christopher Hitchens, who had terminal lung cancer at the time of the interview. He did end up passing away during this research and it would be interesting to examine atheist reactions to his death, as he is obviously an important figure for many. Finally, the last two quotes come from the two respondents who used these authors as a way to define their own atheism. The first of the two was the end of a page-long discussion of the differences he saw between the authors, ending with the statement about how he identified more with Harris and Dennett, as if these were the only representations to chose from. The last respondent is referring to a spectrum of belief presented in The God Delusion in which Dawkins discusses how atheists do not claim to know god does not exist (a 7 on the spectrum) while there are numerous theists who claim to know that 
he does (a 1 on the spectrum). Thus, while respondents discussed how they felt there were no codified rules on atheism, they seem to be finding at least some of that in these authors.

Along with the praise given to the authors, there were criticisms. One criticism was that they had little to offer in the way of identity development or political action.

"I could be wrong here, but I think whatever Dawkins has written, he barely suggests anything. He has just kind of said, ok guys, you're on your own now."

When asked if they felt like these authors were atheist leaders, one respondent said, "If not explicit, but perhaps in implied or implicitly. They may not desire that, but yes." This brings up an important point that I mention in the previous chapter, the point that these authors are not movement organizers or even necessarily movement supporters. They wrote their books before the atheist movement gained the attention is has now, and in fact their books are a large reason for that attention. However, the purpose of their books is not to dispense movement scripts, but simply to criticize religion. Thus, they are not the best source for promoting an atheist movement, even if they do promote atheism. The fact that this is where respondents are getting their information may be a major reason they do not participate in activism or see atheism as a salient identity.

The second, and more prevalent criticism, was their lack of tolerance for religion, which is a common finding (Foust 2009, Cimino and Smith 2011). This criticism often bled into criticisms about the movement in general, proving that these authors are seen by respondents as leaders of the movement as well as that respondents are not being exposed to the national groups, which do qualify their religious criticisms with calls for tolerance. 
Some respondents discussed how the New Atheists' lack of tolerance was a problem for them and felt that their hostility was further polarizing theists and non-theists.

"Now a lot of people will swear by these four atheists. But it's because those people, those four guys, they tell people what they want to hear. You have a lot of atheists who are still recovering from religion. There's still bitterness, anger, mistrust. And so, they're looking for things that make them feel that they belong to someone. They've been rejected, they've walked away, they're recovering. So that makes Dawkins, Hitchens, Dennett, Harris, some of the more extreme statements very attractive."

"I get the sense that atheists are really angry. And sometimes I get the sense that atheists are not tolerant of other religions. I think for me, like for example in reading the God Delusion, I don't see at all a tolerance of other religions. So I would say that that piece of it for me, I really want to be tolerant of other religions."

Over 12 respondents voiced opinions mirroring the statements above, even if they were not directly related to the New Atheists. Respondents were hesitant to be too critical of religion because many of them had religious family members and friends. They also discussed how atheists cannot expect respect from the religious if atheists do not give that respect in return.

"[The New Atheists'] big thing, and what I had to get used to, is that religion is not only unnecessary but it's harmful. That's because I have so many people who are religious and who I love and who are very close to me, that's a tough one to navigate."

"One of the things I like about [my atheist group], and some of the web material that I have read, is that they're not looking to crush religion, and maybe the good things out of atheism as far as social good and the good things out of religion, social goods and whatever they may be, can come together and it doesn't have to be a complete dismemberment of religion. If the deity can be removed from the equation a little bit."

"Kind of the, how they say, hate the sin, love the sinner. That's kind of like what we feel about religion, you know. We don't want to attack Christians, but at the same time, we would love people to think critically." 
"If we expect others to be tolerant of our lack of religion, we have to be tolerant of theirs. I think if atheists are as smart as the data shows, then we should know better than that. We're supposed to be the mature ones in the classroom and we cannot do that if we just say, fuck you you're religious."

The above quotes illustrate not only respondents' hesitancy to criticize religion the way their favorite atheist authors do (all four quotes come from respondents who praised these authors), but also that they feel that there are positives in religion and that atheists should combine those goods with the goods atheists are offering. Further, the last quote states that atheists are "better than that." Again, we see some evidence of conflicting role expectations and the way the New Atheists authors are failing to be the type of atheist these respondents see as good or acceptable. Also note the way the latter two quotes use "we" to talk about atheists as these respondents attempt to speak for atheists as a group, further illustrating the in-group favoritism held by respondents as well as alluding to the expectations they have for other atheists.

A key finding in this area is that respondents are not looking to eradicate religion, though all of them said they would like to see a more secular society. They argue that religion should be given to those who want it and atheists should be tolerant of that, but only if that religion stays out of the public sphere.

"You can believe whatever the hell you want, but it's not reasonable to say, because of my belief, you can't do something. That's, I mean, it's not a society that people can live in in a harmonious way. I don't think it should be tolerated if they want to legislate their beliefs, infringe upon the school system, or refuse medical care. That's the fine line, the reality is that people's beliefs will always affect their actions. There's no way around that. Things like gay marriage or abortion, it doesn't matter if it's not constitutional, they'll vote yes. But you can't tell people they can't believe something. But I would like to move towards a secular society."

"I don't think it's my right to tell somebody else what kind of crazy, stupid ideas they can hold. I don't think it's right to come in with some....in the 
privacy of their own homes they can do what they want. In the public arena, it's different, and I do think that's where we can have a real talk about what is permissible and what isn't."

There is an inherent flaw in this line of thinking, as religion cannot simply stay in the privacy of people's homes. Religion is a salient identity for most who hold it and that part of their identity translates into everything they do, including how they vote and what social policies they support (Anisman et al. 2011). Respondents want to see a more secular society and are tired of religious policies affecting them and their children, but are hesitant to advocate for total displacement and in fact point to the positives it can have, not only for the religious, but for everyone, including atheists. Following Cimino and Smith's (2007) findings that atheists have accepted the failure of secularization to eradicate religion and instead are attempting to make a niche for themselves, my respondents argue that they simply want to see atheism as an acceptable belief and do not need to see religion eradicated.

"I think a lot of atheists want religion to die away and be replaced by a secular society. I want to ultimately create a secular alternative to religion. I used to have a more, in my opinion, immature viewpoint, that enough secularization will just push religion off the table, and it will just diminish. But again, we underestimate how strong beliefs are to people and all that, family, and everything that goes into religion. And unless there's actually a real alternative to religion, which, in my opinion, there isn't a real alternative, secular alternative to religion, then people will see two choices, instead of one."

Thus, the majority reaction of my respondents to the New Atheists' most prominent movement script, criticize, is the desire to qualify that criticism with more religious tolerance. Despite their lionization of the New Atheist authors, they do not practice the major script these authors are dispensing. Respondents also discussed their 
reactions to other movement strategies and scripts, including the Brights movement, the billboards being put up by the national groups, and the overall idea of forming a movement based off of atheist identity. First, respondents echoed previous studies in their reactions to the Brights movement and argued that this label was condescending (Foust 2009; Cimino and Smith 2011). Further, many argued that atheists need not to relabel themselves but to present a better image of atheism to the public.

"I think they're trying to fix the wrong problem, the wrong dilemma. Because, even if you get this name that everyone agrees on, this description that everyone agrees on. There's still going to be good, bad, and nasty atheists. There's going to be people, who cares if you're called a Bright or Fluffy, if you're not approachable, if you're not going to have a conversation, they're still going to think of that negative aspect of atheism when they think of you."

"I think that relabeling ourselves is hiding. Soft-peddling that is an immediate concession and saying there is something wrong. We should not. There should be more clarity on what this is, give examples, using people who don't mind being public."

"Maybe a different word would be good because a lot of people don't understand what atheism is. And Brights or the Bright movement, I don't think that would be a good name. It's a little conceited I think. Because there are religious people who are extremely bright. You can argue that there's a disconnect between their rationality and their beliefs, but it doesn't make them stupid."

"I don't know why [Dawkins] was doing that. It seems to me not the right, if you were going to do it at all, that seems like not the right word to use because it seems to antagonize people. Now, I know that confrontation is good and that's how stuff happens, but, I mean, it sounds like an insult to everyone else. We're so special and good."

Overall, respondents felt that relabeling atheism is unnecessary at best and harmful at worst. The first two quotes illustrate how respondents are aware of the negative view of atheism and that they think there needs to be more positive atheist representations as opposed to just a name change. The final two quotes illustrate the desire for religious 
tolerance and respect discussed earlier. These respondents felt that calling themselves

"Brights" in contrast to "dull" believers was conceited and antagonizing.

Following this discussion, I asked respondents how they felt about the different labels within the secular community. When asked if they felt that atheists were different from other nonbelievers in terms of goals or if they felt that they should all unite under one term or movement, respondents generally felt comfortable with the idea of joining forces with other forms of non-belief.

"I think that the nonbelief umbrella seems like a totally reasonable term to organize all of the kinds of people who may have small disagreements about their level of commitment to nonbelief. Like, agnostics are like, well, it's pretty much not true, or they're deists or they leave a little bit of space for god's possibility than I do, but I'm totally happy to be in that camp with them."

"Because you have an organization like that, people say, why did you start this atheist thing, why didn't you just go an join the humanists? I think the atheist...if you aggregate all the groups, I don't think we'd be contradicting ourselves. Non-belief, if you could have maybe a single catchall. I cannot see why, as a group, I think they're natural allies.

"I don't think that there is too much factionalism because at different events, it's sort of like nonbelievers, secularists, agnostics, atheists. They all pretty much don't believe in god when it comes down to it. There's just slight variations. It might be good to sort of have an umbrella name to cover everyone."

These quotes further illustrate the similarities in respondents' views with the scripts being dispensed by the national groups that they are mostly unaware of. The national groups argue that non-believers need to come together to form a cohesive movement, while the New Atheist authors criticize agnostics and humanists for fence-sitting. This further illustrates how the label "atheist" is not what is important for these respondents and that they do not see affirming atheist identity as a primary goal. 
In regards to national groups using billboards, t-shirts, bumper stickers, and other "wear your atheism on your sleeve" tactics, respondents had mixed responses. While they thought these strategies were fun and were a way to get atheism in the public eye, they were unsure how effective they were as a political strategy.

"I don't think that it would help much, you know, like for me to put an atheist fish on my car. I suppose it could. I'm not sure. I never thought of that."

"I think that kind of stuff is goofy without a real public and visible debate. Just having a bunch of kids make some t-shirts isn't...I don't think those are the kinds of things that really are very public and confrontational. But I think the t-shirts are cute and I would totally wear one."

"I think it's totally obnoxious to walk down the street and see a Christ-y sign. It's just, back off, you know. So, immediately I feel a kind of repulsion to the idea that atheists would do that too. Because, it's an invasion of mental space, right? So I guess I'm a little uncomfortable with advertising in the same kinds of ways. But, maybe that's a tactic."

"They have the billboards, which I think are very eye-grabbing or you know, all that stuff. Billboards are good, but I mean, there's just about this much money that you can spend on it. And the thing is, you say that, you know, and then it's gone. What is the lasting effect that is has? Probably nothing much. But in terms of social policy and things like that, I don't think we are very organized.

As these quotes illustrate, respondents feel that the billboards and t-shirts are not political enough. Even though the respondent from the second quote said he would wear one of the goofy t-shirts, he did not feel it was public or confrontational enough to make a difference. Once again, we see a lack of desire to affirm an atheist identity and more of an emphasis on legislation and political action, a major script offered by FFRF.

Building off of the last quote in which the respondent alludes to his sense that atheists are not very organized, I discussed with respondents how they view the overall 
atheist movement activity that they see. While over half of respondents were unaware that such a movement existed, three respondents talked about its similarities to the gay movement.

"Well I do think that the gay movement is one of them in terms of being out there, being seen, and not hiding ourselves, not having to hide ourselves. Like, marching in parades, the Richard Dawkins out campaign, wearing our emblem on our sleeves, adopting the red-letter A like the pink triangle. I think the gay movement has, what they have done is a good model for what we've done. I don't think we've, I don't think we've suffered nearly like gays have."

"Oh yeah, and we really followed [the gay movement] model. We really believe that they did a really good job of gaining acceptance. And so we're kind of trying to move in the same direction."

"Well, it's very similar to how the gay movement originated. We just wanted, there was a lot of negative stereotype around the word gay and homosexual. There's a lot of negative stereotype around the word atheist. It was just, basically to just get acceptance in society. Those who are silent atheists to know that they're not alone, to know that there's a group of people they can identify with, and to make more visible that 15-20 percent of society are nonbelievers."

These respondents were very aware of the atheist movement's appropriation of gay movement strategies, though all three of these respondents are very active in the atheist groups, making them more prone to be exposed to these kinds of comparisons. However, other respondents noted a lack of cohesion and national presence in the movement activity they saw, with one respondent arguing that the gay movement was successful because they had clear goals, something they feel that the atheist movement is lacking.

"So [the gay movement] must have had a lot of local chapters involved and there must have been a national organization which collected all that money and the lawyers to track the legislation, to call the senators and things like that. So it was very visible. And they had very clear goals. They could spell it out. We want marriage. What do atheists want?"

"At this point, I think we are agendaless. Unless we have some kind of a 
national structure, I think we will just be flailing in the wind. I mean, we can't even have a consistent group at a coffee shop. I think we are flailing for critical mass. And we are probably a long way away from there. I feel like there is not enough communication."

"I don't know if it's a movement, it doesn't really seem like a movement to me. It just isn't present, it isn't something that's talked about in the media. There is always religiously inspired legislation out there that seems to be really present, as opposed to counter arguments. A movement has to define what its aims are and has to hone their argument. It doesn't seem to be there. We have sort of secular arguments, but that's all policy driven, it's not ideological like I think a movement would be."

Thus, while over half of the respondents were unaware of the movement, those that were aware felt that is has thus far been unsuccessful. While they see attempts at movement action through the billboards and Brights movement, they do not necessarily identify with these strategies or see them as powerful enough to change minds. Further, they are not being exposed to any political activism in the atheist groups they attend. These findings lead directly into the next and final section of this chapter in which I will discuss why all but three of my participants have chosen not to participate in atheist activism and what it would take for them to change that.

\section{A Lack of Identity Salience Leads to a Lack of Activism}

Out of the fifteen participants, only three felt they had participated in any activism. Two of those three were simply group leaders and have never "been in any marches or anything like that." To begin, I asked what respondents felt activism was, and most referred to being in marches or enacting legislation, which only one participant had actually participated in. Only five respondents pointed to coming out or being an atheist in public as an activist strategy. When I asked them if they felt that just coming out as an 
atheist was activism, most had not thought about activism in that way. For example, when

I asked a participant if he felt coming out was a form of activism, he responded with,

"It's certainly risky. You're totally changing my mind now. I was totally like, I'm not sure her thesis is warranted, but now the more that you get me to think of it, it is very much so, just on your census form marking none."

But others felt less confident in this strategy and one respondent argued that coming out may not be very useful and will only further pit theists against atheists.

"Just by announcing that you're an atheist, I don't know that there's a lot of value in that. Umm, yeah, I guess we probably do, we need to come out, but if we come out too forcefully, there's the possibility of the religious side digging their heals in further."

After gaining an understanding of what they defined as activism, I asked respondents if they had participated in any activism themselves. The overwhelming response was no. While three participants are leaders of atheist groups and one participant did engage in legal action against her son's school regarding religious proselytizing, the majority response was that they had not participated in any activism, though many would like to. Some respondents described different actions they hope to take in the future.

"At this point, since I feel that I'm a fledgling atheist, I would like to join an activist group At this point, I think I'm too young in my...to start something. But if there was a group that says this is our thing, we have a political agenda and this is what we want to do, I'll be there."

"Write a little more. Write a lot more. Talk a lot more. Maybe challenge some theists overstepping. Trying to bring about the awareness of evolutionary theory."

"Well I used to, originally, I thought it was just being a part of a protest, march. And now I see it as, the type of activism that I would strive towards is one that's at the grassroots level, where the communities are, where the people are. And not just the type of events that you see on TV 
like march protests. The type of activism that seeks change, the type of change that will take decades and not over the night change."

"Yeah. I've thought about how do I approach these people and just say, hey I'm a resource for you. The thought's been there but the action hasn't been. But I think that would be a realm that I would want to play in.”

However, despite their intent, none of the four respondents above have actually followed through on their activist plans and, as the last quote nicely states it, "The thought's been there but the action hasn't been there." Why not? A common complaint was that respondents led busy lives and they simply did not have the time to participate in these kinds of things.

"Mostly I am a victim of my own schedule. There are debates that I'd love to go to. They offer a lot of things that you can, and if you can't find it, you can create it. So, no, that part, I really like the organization. I'd really love to help out more but I've got a full time job and two kids."

"Everybody's busy in life, I have my own other battles to fight. Being here at school, trying to keep my little family afloat. So, just, daily life gets in the way of that kind of stuff."

These respondents support the idea of atheist activism, but they have the luxury of freeriding on the actions of national groups and leaders because, as discussed earlier, they do not experience stigma in their everyday lives and thus see their families and jobs as bigger priorities. Other respondents discussed how they felt that the movement was too disorganized, that activism for the sake of atheism was not a priority, and further, that atheist activism overall was negative.

"There are things that I am willing to do, but if it was specifically for the purposes of atheism, I'm kind of of the belief, it's like rallying behind nonstamp collectors or non-golfers. You have to have something beyond that point. Human rights, I could rally around a secular, atheist group that wanted to rally around that." 
"Specifically backing an atheist identity or issue, no. I can see one for a secular approach to how legislation is formed and for defending the right to not believe. It would really need to be more of a human rights issue, because you have the right to not believe, but specifically an atheist, I guess it seems foreign to me. You've got such a diverse population and why people don't believe is always going to be different."

"I don't think it's right to organize around disbelief. That actually is worrisome to me. I'm worried that it will become like a religion. And it will begin doing things that religions have done throughout history. My belief system, or lack of belief, doesn't have anything to do with anybody else. And I don't want to push it on anybody else, it's for me."

\section{Conclusion}

As the above quotations illustrate, many of my respondents felt that rallying around an atheist identity was either meaningless or harmful, which is the opposite of what the leaders of this movement are trying to promote. Overall, there is a definite disconnect in the movement scripts being offered by national groups and authors and the scripts and views of individual atheists. While respondents want to see a push for secular policies and a niche built for atheists in which atheists and theists are equally respected, they are not willing or unsure how to go about making those changes. Further, the overall script that the national groups offer is that atheism is a stigmatized identity in need of civil rights and equal treatment. While my respondents would not disagree with that statement, for them, atheism is not a salient identity and this is a major barrier to their desire to engage in any activism. 


\section{CHAPTER 6: DISCUSSION AND CONCLUSIONS}

This section gives a summary and synthesis of the findings, placing them within previous theoretical and empirical findings, and discussing the implications of these findings in terms of atheist identity and the future of the atheist movement. I will also discuss areas where this research brought to light certain questions or findings in need of further research.

Upon examining the scripts being dispensed by atheist movement leaders and comparing those scripts to the reactions and actions of individual atheists, three important themes stand out. The first theme I will discuss is that, while the national atheist groups are attempting to make atheism into a collective identity in need of affirmation and equal rights, individual atheists do not agree that atheism is a salient identity nor do they feel the same sense of relative deprivation that these groups are trying to bring to light. This leads into the second theme I will discuss in this section which is the limits that the gay analogy has when applied to atheists. Being gay and being atheist do have some similarities, but there are limits to this analogy that may hurt not only the atheist movement, but the gay movement as well. Third, I will discuss the emergent aspects of the atheist movement, using my data combined with theory on social movements to highlight the ways that the atheist movement is going through similar stages as other movements and encountering many of the same obstacles, though they are also experiencing some unique issues with regard to identity and strategy.

\section{No Sense of Relative Deprivation, Low Levels of Social Identification}

Though public opinion polls show a strong stigma towards atheists, responses 
indicate that stigma is not enough to spur all atheists into action. National groups have been trying to heighten awareness of collective relative deprivation (Brewer and Silver 2000), however few of my respondents are exposed to these scripts. Further, most do not experience stigma in their everyday lives or see a need for a movement strictly geared towards atheist identity affirmation. While most are sympathizers, they are not activists, and there is no real passion for action in the future. What accounts for this lack of passion? Again, it comes down to a lack of experienced stigma. While some respondents discussed how they were hesitant to discuss their beliefs for fear of a negative reaction, only a few of them had experienced actual discrimination based on their beliefs. Brewer (1991) discusses how collective identities are often stronger when they are stigmatized, as stigmatized individuals find strength in numbers. Further, she argues that action is more likely when group members feel a sense of shared deprivation. However, respondents in this sample, while agreeing that atheists are stigmatized, do not see or experience enough stigma for it to translate into a desire or sense of urgency to take action. My respondents do not see much of a personal cost associated with maintaining group membership and thus do not feel as connected to a collective identity.

The lack of stigma seen by my participants can be attributed to one of two factors, and perhaps it is both. First, my sample comes from secular Portland, where being an atheist is just as common as riding a bike. Thus, being stigmatized for being an atheist is less common in Portland than a highly religious city in the Bible Belt. Another factor is that atheists can blend in. Atheism is not a readily identifiable trait and one does not have to come out in dress or public presentation in order to be an atheist. Taken together, it is likely that the lack of stigma experienced in my sample stems from a lack of necessity to 
be "out." If atheists do not experience discrimination and are able to live their lives in relative peace, they are not likely to see a need for activism. Finally, all of my participants had attended at least some college and university campuses are notably freethinking and venerate reason over religion. Thus, it is likely that they have some biased thinking in regards to the prevalence and acceptance of nonbelief.

Another major reason for their lack of action that was discussed in the previous chapter is the lack of salience the atheist label has for this sample. Brewer and Silver (2000) discuss how movement groups need to elicit high levels of social identification in order for individual identities to translate into collective identities and collective action. While they enjoy reading atheist texts and many attend atheist groups, when it comes to affirming their beliefs in public, or better yet as a way of activism, respondents felt that it was just not a priority for them; they had low levels of social identification with atheism and instead saw it as a personal choice or label. Further, they were able to either "pass" or simply ignore their atheism when it came to being around their religious friends and family members and many discussed how they has more religious friends than atheist friends. Some participants also discussed how they would be open to marriage with a believer, further illustrating the lack of boundaries they draw around their beliefs and others' beliefs.

Benford and Hunt (1992) discuss how movement leaders will typify opponents as immoral or villains in order to galvanize and focus sentiment while concurrently scripting movement members as the embodiment of good; the "negation of all that the antagonists represent" (Pp. 89). As the content analysis findings chapter illustrated, this is one of the major scripts being offered to atheists, with the religious being cast as ignorant and 
hypocritical and atheists as smarter and more reasonable. Not only should this foster ingroup favoritism (Brewer 1991), but it should, according to Benford and Hunt (1992), galvanize support from those who identify with these stereotypes. What this research found however is that while atheists do gravitate towards authors who engage heavily in this type of scripting, they do not practice it themselves and instead desire more tolerance from their atheist leaders. As Benford and Hunt argue, "Movement performances incongruent with audience interpretations of their empirical, experiential and cultural realities may fail to resonate or move them to participate actively in the collective drama" (Pp. 103). Thus, even though participants are entertained by harsh critiques of believers and would support the eradication of religion in a "perfect world", the call for them to engage in this criticism is incongruent with their values. Instead, they see advocating for separation of church and state as a priority as this would allow for believers and nonbelievers to coexist harmoniously (or so they think). While church/state separation scripts are offered by national groups, my respondents are not exposed to those scripts, leaving them feeling unfulfilled and misrepresented by the New Atheist authors.

The issue of relabeling a stigmatized identity, as the Brights are trying to do, is reminiscent of the gay rights movement and the relabeling of homosexuality. Armstrong (2002) explains how gay liberationists urged people to identity as "gay" as opposed to "homosexual." They saw "gay" as "positive, self-defined, and non-apologetic" (P. 71). They were rejecting the term that mainstream society and science used to categorize them, making them a sexual minority, and developed a term that would make them like an ethnic group instead. However, respondents in this study and others (Foust 2009) argue that, while this may be a useful strategy, the approach taken by the "New Atheists" 
is condescending and conflicts with the desire for religious tolerance expressed by respondents.

Finally, respondents indicated that there was no real representation of atheism for them to mold their own actions and beliefs towards. While they argued that secular humanism was a place to find a "code to live by," they were struggling to find ways to identify as an atheist. As Brewer and Silver (2000) discuss, in order for someone to identify with a collective identity, there needs to be a prototype of that identity to mold behaviors toward. Many of my respondents found some of this in the New Atheist authors, though a majority felt that these authors' atheism were too extreme to replicate. Further, and something that was not discussed by my participants but has been discussed by other researchers (Hutchinson 2011, Peterson 2007) is that these authors are on another level than the average atheist in terms of intellect and prestige. Thus, while they are intellectual atheist celebrities, they are not necessarily representations that my participants see as attainable.

\section{Limits to the Gay Analogy}

National groups suggest that the atheist movement is similar to the gay movement and it is important to discuss the implications and limitations of this analogy. First, it is worth noting the consequences the appropriation of the coming out metaphor has for the gay community. Researchers argue that this appropriation could be taking the attention and momentum away from the gay community as well as lessening the impact of their strategies. Anspach et al. (2007) suggest that the atheist appropriation of this metaphor "suggests that homosexuals, unlike atheists, no longer need to be in the closet for fear of 
oppression...these statements of comparison and equivalence elevate and strengthen the status of atheists, but appear also to underestimate, and possibly undermine, the identity politics of homosexuals" (Pp. 109). Further, as we saw in the content analysis, this appropriation is often justified with statements about how atheists represent a larger group than homosexuals (and Jews) and thus they should see even more success by using these strategies. Anspach et al. argue that while this may be an effective strategy for atheists now, it could lead to polarization between homosexuals and atheists, a coalition that would be beneficial for both groups. "Regardless of their intention, the atheist movement's use of the closet metaphor still privileges a particular interpretation of homosexuals' experience: that 'coming out of the closet' is easy and successful, on the one had, and that homosexuals are no longer a marginalized group on the other" (Anspach et al.: 113).

Another issue is the fact that atheists experience much less discrimination than gays do. Yes, the public opinion polls do have atheist losing to gays in terms of acceptance and chances to win a presidential campaign, but these opinions do not translate into real life discrimination for atheists nearly as much as they do for gays. Though the atheist movement has appropriated strategies from the gay movement, religion is move available for deviation than sexuality and atheists do not see discrimination with regard to things like marriage, housing, and employment, which were and still are major obstacles for the gay rights movement. Gans (1994) discusses how American religiosity has become a private activity and that this leads to American religious individualism in which religion is based on faith, not lineage. He argues that "the originally Protestant notion of direct communication between deity and individual 
have now spread over most mainstream American religions" (P. 581). Thus, people are not required to believe what their parents believed, and in fact about half of American adults have changed religious affiliation at least once during their lives (Pew Forum 2009). This means that it is fairly simple to change your religious identification and this is in fact a common phenomenon. Even though atheism in itself is still seen as deviant, the point is that religious identification is voluntary and subject to change (Gans 1994) In contrast, sexuality is a very public thing. To be a "couple" requires a public presentation of one's relationship. Further, the idea of someone changing their sexuality is still seen as deviant by many, though we are seeing strides towards acceptance.

Atheists do experience discrimination and I do not want to discredit that. The point is that it is much less difficult to live your life as an atheist than as a gay person today, especially in terms of institutional barriers. Thus coming out as atheist is not as much of a priority as coming out as gay. Further, Armstrong (2002) points out that Harvey Milk called for gays to come out as a political strategy; as a defense against the California ballot measure 6, also known as the Briggs Initiative, that would have threatened the jobs gays and those who supported them from working in California's public schools. However, while the atheist movement is attempting to use the coming out metaphor as a political strategy, there is no real danger for atheists if they shy away or simply free-ride on those who are coming out. There are no ballot measures seeking to threaten their jobs or ways of life. In addition, a majority of my participants indicated that coming out as a political strategy was a foreign idea to them and they felt that the "wear your atheism on your sleeve" tactics of the national groups were silly and probably ineffective. Again we see respondents supporting church/state legislation over atheist 
identity affirmation.

This leads to my final critique of this analogy in that Armstrong (2002) discusses how the gay movement's success came through unity through diversity; the primary goal was the expansion of the range of ways to express gay identity. This is not what appears to be happening in the atheist movement. While the national groups and many of my respondents did discuss how nonbelievers of different stripes should come together and unite under one term, the atheist movement's primary goal is not the expansion of the range of ways to express nonbelief identity. Instead, it is about organizing nonbelievers in order to successfully enact church/state separation and more positive societal perceptions of nonbelief. Further, Armstrong discusses how the gay identity movement arose when affirming gay identity and celebrating diversity replaced societal transformation as goals. As we see with the New Atheist authors, societal transformation is still a major script being offered by atheist representatives. However, neither societal transformation nor affirmation of atheist identity are major goals of my participants. Rather, they simply want to be less affected by religious social policies, but are not that enthusiastic when it comes to do anything about it themselves.

Thus, while gays and atheists do have some similarities in that they are both groups of stigmatized individuals that are able to "pass" or "affirm" their identities due to the discreditable status of their stigma (Goffman 1961), the stigma plays out in different ways and gay tends to be more of a salient identity than atheism. In a recent presentation, a researcher discussed how her interview participants who were both gay and atheist discussed how they were out as gay, but not as atheist, mostly because they felt that being gay defined them more than being atheist did (Schutz 2012). So, while the atheist 
movement has seen some successes in their appropriation of gay movement strategies, there are limits to these analogies and those limits are possible inhibitors to the atheist movement's success.

\section{Emerging Movement}

Identity movements, and social movements in general, go through three stages raising awareness, unifying and building community, and then mobilization. Freeman (1999) lays out three essential requirements for a movement to be built - having a preexisting network, highlighting commonalities, and a precipitating event. First, there needs to be a preexisting communications network within the social base. "Masses alone do not form movements, however discontented they may be" (Pp. 7). Groups of previously unorganized individuals may spontaneously form into small local associations, but they will not form a successful movement without an existing network. This is largely what we are seeing from the atheist movement. As discussed in the previous chapter, over half of my participants attend atheist groups. However, they discussed how these groups were not at all political and were simply for social purposes. This, however, does not mean they are useless. They are in fact a way of raising awareness and building community among atheists. Further, the national groups are political and, if my participants decide to look into them, are a way of further raising awareness of atheist issues and possibly recruiting more activists.

The second essential thing Freeman argues is needed for the formation of a movement is that the existing network be co-optable, meaning they are composed of likeminded people whose backgrounds, experiences, or locations in the social structure make 
them receptive to movement ideas. Interviews from this study show that this is where the atheist movement is finding problems. While there is a community being built, that community is not satisfied with the small amounts of movement activity that it is exposed to. Further, while it appears that my respondents have similar backgrounds, experiences, and locations, it could be precisely because of their similar locations and backgrounds that they are not co-optable. They are all college educated people living relatively stigmafree lives, marrying and working as atheists without any real consequences. Thus, there is no need or passion for action as they have already reached a desirable status in society. This likely accounts for their desire for secular policies without any real desire to engage in activism that would enable those policies to be put into place. So, while my respondents may be co-optable on paper, they are not in reality.

One thing to consider is the atheist movement's use of the internet as a main source of communication. Respondents discussed how they felt a lack of emotional connection with other atheists, even fellow group members, because there was not enough face-to-face interaction or any real bonds being formed. This was in part due to the structure of the groups, but it is also because the movement relies on atheists to connect through the internet. While we saw how the internet can be a monumental tool for political action, for example in the Arab Spring, these people already had an emotional connection and a community. Further, they were reacting to severe and longstanding oppression. For the atheist movement, there is not an emotionally connected community to build from nor a serious oppression to address, thus we are seeing the internet as almost hindering their movement as opposed to helping it in regards to community building and forming co-optable constituents. Gladwell (2010) argues that 
high-risk activism, such as the sit-ins during the Civil Rights movement, is a "strong-tie phenomenon" and that activism centered around social media like Facebook and Twitter foster "weak ties" in which people are able to support numerous causes at once without any real commitment. While he argues that weak ties have their strengths, such as exposing people to new ideas, weak ties do not lead to high-risk activism.

"Social networks are effective at increasing participation - by lessening the level of motivation that participation requires. The Facebook page of the Save Darfur Coalition has 1,282,339 members, who have donated an average of nine cents apiece. The next biggest Darfur charity on Facebook has 22,073 members, who have donated an average of thirty-five cents. Help Save Darfur has 2,797 members, who have given, on average, fifteen cents. In other words, Facebook activism succeeds not by motivating people to make a real sacrifice but by motivating them to do the things that people do when they are not motivated enough to make a real sacrifice. We are a long way from the lunch counters of Greensboro" (P. 4).

My point in showing this quote is that there are consequences that come with the ease of access given by the internet and social networking sites. While atheists are able to connect with other atheists more easily, which is especially important for atheists in more religious parts of the country (and world), it is not likely to promote mobilization or "high risk activism". Someone may "like" Richard Dawkins on their Facebook page and donate twenty cents to his cause, but that person is probably not going to organize a protest. My interviews mirror Gladwell's discussion in many ways. Most of my participants do not feel strongly tied to an atheist movement and many of them desire more emotional connection within their atheist groups, leading to a lack of passion for action.

Finally, Freeman argues that there needs to be a precipitating event - either a crisis that galvanizes the network into spontaneous action or someone organizing new organizations that disseminate new ideas. A few researchers (Hout and Fischer 2002, 
Jacoby 2004, Saxton 2009, Smith 2011), as well as participants, pointed to 9/11 and the politicization of religious politics as a catalyst for the atheist movement, and others have pointed to the popularity of the New Atheist authors as evidence of this societal shift, but these events have not encouraged my participants to take action. While the events were pointed to as a reason for taking on the atheist label or questioning religion, they have thus far failed to elicit enough passion for action from my respondents.

\section{Conclusions and Future Research}

Analyzing the recently popularized atheist movement reveals its many connections to other identity movements. The atheist identity movement has utilized many of the same strategies and previous movements and has experienced many of the same problems. Bernstein (1997) discusses how the presence of a strong opposition and negative interactions with the state can often lead to dissension within the movement community. That dissension can result in factionalization, which produces moderates who focus more on education and traditional lobbying tactics and radicals who will focus on criticizing dominant values. Bernstein (1997) states, "Radicalization in the movement can stem as much from reaction to movement leaders as from reactions to the political context" (P. 541). The atheist movement has experienced very strong opposition, from media outlets framing their movement in a negative light to barriers in many states, like Texas, not allowing them to buy billboard/bus space for their "coming out" campaign (McKinley 2010). Stemming from this opposition, groups like the American Atheists and Freedom From Religion Foundation advocate coming out and educating the public about atheism, while also using traditional lobbying tactics in court cases fighting for the 
separation of church and state. Conversely, the "New Atheists" reacted to this opposition radically and, thanks to their wealth and status, were able to publish best-sellers. This has in turn led to dissension in the secular community about what kind of identity atheists should be deploying and what the agenda should be.

While understanding the variations in national group strategies is important and expands on prior identity politics research (Anspach et.al 2007, Cimino and Smith 2007; 2011, Ritchey 2009, Smith 2011), the key finding from this particular study is that the strategies and scripts being dispensed by national groups are not always reaching individual atheists. When the strategies do reach atheists, they do not always agree with or act on them. Many of my respondents enjoyed reading the "New Atheists," and a few were even pushed from doubting god or a being to identifying as an atheist by reading them. However, very few actually deploy their identity the way these authors are advocating for. Instead, my respondents seem to fall more in line with the scripts dispensed by the American Atheists and the Freedom From Religion Foundation, despite many of them never having heard of these groups or read their publications. They agree that atheists should come out, but not some much in a political sense as much as just in the sense that they should not hide their identity. Instead, respondents are primarily interested in church/state separation issues

In summary, the atheist movement is an emerging movement and is still attempting to raise awareness and build a large community in which to mobilize. Many of my participants attended atheist social gatherings and frequented atheist websites and literature, meaning that there is an atheist community being built. This research sought to examine the ways in which the atheist movement used identity politics and mirrored 
previous identity movements. What I found was that there was not really support for an identity movement at all. While the national groups are attempting to frame atheism as an identity in need of rights and acceptance, my participants are hesitant to identify with those goals. Instead, they see atheist groups as a way to learn more about atheism and find representations of the atheist role that they identify with. Compounded with the lack of desire to participate in activism directly related to affirming atheist identity, it seems that these groups more closely mirror affinity groups or Ritchey's (2009) “communities of practice". While these groups could very well transform into a successful movement as we saw with the gay rights movement, interview responses indicate that this is not happening as of yet. Respondents are not deploying their identity strategically and have conflicting views as to how to go about being an atheist and what kinds of atheism to support. Overall, atheism is a label for my participants, not an identity, and this is likely to hinder national attempts at identity politics.

\section{Future Research}

Findings from this study raise numerous questions for future research. First and most importantly, this research should be replicated in other places in America. Foust (2009) talked to atheists in North Carolina and Schutz (2012) talked to atheists in Tuscon, Arizona. Both researchers found similar reactions to the New Atheist authors and similar reasons for attending atheist groups. However, these studies did not look at the ways that atheists are reacting to national identity politics. Atheists in secular Portland are likely to have different experiences regarding discrimination than someone in a more conservative area of the country and they may feel differently about the need for an atheist identity movement. Second, while my findings suggest that individual atheists do not identify 
with an atheist identity movement, there is evidence that other atheists do identify with this type of movement. Take the recent Reason Rally in D.C., for example. This rally, held in March 2012 and regarded as the "Woodstock for atheists," was all about promoting atheist identity and thousands of nonbelievers came to show their support. Thus, there is more to the story than this research can offer. What made this rally so successful? What is it about this time in history that is conducive to the recent increase in religious disaffiliation? Is the recent popularity of atheist authors and groups simply a fad or is it a trend that is going to continue? What makes someone choose to be an atheist activist over simply identifying as an atheist?

Another area in need of further research is this study's findings on the limits of using the internet as an identity movement strategy. With continuous changes in technology, future movements are going to have to find ways to bridge the gap between the ease of access and large dissemination granted by the internet and the emotional connections that can really only be made on a face-to-face level. Examining how the atheist movement continues to utilize the internet as a strategy, and whether it is successful or not, would be an important contribution to modern social movement theories.

A final area for future research, and research that I hope to be a part of, is taking an intersectional approach to examining this movement. Other researchers have begun to elucidate the ways that the atheist movement is largely an intellectual, white man's movement and that its philosophical arguments berating believers are inaccessible to minority groups and women who often have lower levels of education or come from strong religious communities (Hutchinson 2011, Peterson 2007). Future research should 
look at how this movement inadvertently excludes these groups as well as what the movement is doing to address these issues. While a few of my respondents were nonwhite, this research did not seek to examine this aspect of my participant's identity. Is being an atheist more or less salient for those with salient ethnic identities? Finally, is there a population of non-educated atheists? Research indicates that atheism and education are positively related, but is this true for everyone? How does one come to atheism if they do not go to college and how does their atheism differ from those in this study?

All of these questions, and many others, have yet to be addressed by sociological research. As the sociological study of irreligion is being studied more and more, I hope to see these questions being addressed, and I hope to address some of them myself. 


\section{REFERENCES}

American Atheists. www.atheists.org.

Anisman, Hymie, Kimberly Matheson, and Renate Ysseldyk. 2010. "Religiosity as Identity: Toward an Understanding of Religion From a Social Identity Perspective." Personality and Social Psychology Review 14(1): 60-71.

Anspach, Whitney, Kevin Coe, and Crispin Thurlow. 2007. "The Other Closet?:

Atheists, Homosexuals and the Lateral Appropriation of Discursive Capital.” Critical Discourse Studies. 4(1): 95-119.

Armstrong, Elizabeth A. 2002. Forging Gay Identities: Organizing Sexuality in San Francisco, 1950-1944. Chicago: University of Chicago Press.

Baggini, Julian. Atheism: A Brief Insight. New York: Sterling Publishing Co.

Bainbridge, William. 2005. “Atheism.” Interdisciplinary Journal of Research on Religion. 1(1): 1-24.

Beit-Hallahmi, Benjamin. 2007. "Atheists: A Psychological Profile.” Pp. 300-318 in The Cambridge Companion to Atheism, edited by M. Martin. Cambridge, New York. Cambridge University Press.

Bellah, Robert N. 1967. "Civil Religion in America.” Daedalus, Journal of the American Academy of Arts and Sciences 96(1): 1-21.

Benford, Robert D. and Scott A. Hunt. 1992. "Dramaturgy and Social Movements: The Social Construction and Communication of Power." Sociological Inquiry. 62(1): $36-55$.

Berger, Peter. 1992. A Far Glory: The Quest for Faith in an Age of Credulity. New York: Free Press. 
Bernstein, Mary. 1997. "Celebration and Suppression: The Strategic Uses of Identity by the Lesbian and Gay Movement.” The American Journal of Sociology. 103(3): $531-565$.

Bernstein, Mary. 2005. "Identity Politics.” Annual Review of Sociology. 31: 47-74.

Bernstein, Mary. 2008. "The Analytic Dimensions of Identity: A Political Identity Framework." Pp. 277-297 in Identity Work in Social Movements, edited by J. Reger, D.J. Myers, and R.L. Einwohner. Minneapolis, MN: University of Minnesota Press.

Blumer, Herbert. 1969. "Collective Behavior.” Pp. 167-222 in Principles of Sociology, edited by A. McClung-Lee. NY: Barnes and Noble.

Bremmer, Jan N. 2007. “Atheism in Antiquity.” Pp. 11-22 in The Cambridge Companion to Atheism, edited by M. Martin. Cambridge, NY: Cambridge University Press.

Brewer, Marilynn B. 1991. "The Social Self: On Being the Same and Different at the Same Time." PSPB 17(5): 475-482.

Brewer, M. B. and M. D. Silver. 2000. “Group Distinctiveness, Social Identification, and Collective Mobilization.” In Self, Identity and Social Movements, eds S. Stryker ,T. J. Owens and R. W. White, pp.153-171. Minneapolis, MN: University of Minnesota Press.

Bullivant, Stephen. 2008. "Research Note: Sociology and the Study of Atheism". Journal of Contemporary Religion, 23(3): 363-368. 
Carpignano, P., Andersen, R., Aronowitz, S., \& DiFazio, W. 1993. "Chatter in the Age of Electronic Reproduction: Talk Television and the 'Public Mind'.” Pp. 93-120 in The Phantom Public Sphere, edited by B. Robbins. Minneapolis, MN: University of Minnesota Press.

Charmaz, Kathy. 2006. Constructing Grounded Theory: A Practical Guide Through Qualitative Analysis. Sage Publications.

Cimino, Richard and Christopher Smith. 2007. "Secular Humanism and Atheism Beyond Progressive Secularism.” Sociology of Religion. 68(4): 407-424.

Cimino, Richard and Christopher Smith. 2011. "The New Atheism and the Formation of the Imagined Secularist Community." Journal of Media and Religion. 10: 24-38.

Crossley, Nick. 2002. Making Sense of Social Movements. Philadelphia, PA: Open University Press.

Dawkins, Ricard. 2006. The God Delusion. Boston: Houghton Mifflin Co

Dennett, Daniel. 2006. Breaking the Spell: Religion as a Natural Phenomenon. New York: Viking.

Dolak, Kevin. 2010. “Ad Campaign Promoting Atheism Across U.S. Draws Ire and Protest." ABC News, Dec. 5. Retrieved Nov. 10, 2011. http://abcnews.go.com/US/ad-campaign-promoting-atheism-us-draws-ireprotest/story? id=12314529\#.TsG1aMNFu7s

Edgell, Penny, Joseph Gerteis, and Douglas Hartmann. 2006. “Atheists as 'Other': Moral Boundaries and Cultural Membership in American Society." American Sociological Review. 71(2): 211-234. 
Freedom From Religion Foundation. www.ffrf.org.

Freeman, Jo. 1999. "On the Origins of Social Movements." Pp. 7-24 in Waves of Protest: Social Movements Since the Sixties, edited by J. Freeman. Maryland: Rowman and Littlefield Publishers Inc.

Foust, Christine H. 2009. “An Alien in a Christian World: Intolerance, Coping, and Negotiating Identity Among Atheists in the United States.” Master's thesis, Department of Religion, Wake Forest University.

Gamson, William. 1990. The Strategy of Social Protest. Belmont, Calif. : Wadsworth Pub.

Gans, H. J. 1994. "Symbolic Ethnicity and Symbolic Religiosity: Towards a Comparison of Ethnic and Religious Acculturation. Ethnic and Racial Studies 17(4): 577.

Gervais, Will. 2011. "Finding the Faithless: Perceived Atheist Prevalence Reduces AntiAtheist Prejudice." Personality and Social Psychology Bulletin. 37(4): 543 -556.

Gladwell, Malcolm. 2010. "Why the Revolution Will Not Be Tweeted." The New Yorker, October 4 . http://www.newyorker.com/reporting/2010/10/04/101004fa fact gladwell

Goffman, Erving. 1959. The Presentation of Self in Everyday Life. Anchor Press: Doubleday.

Goffman, Erving. 1961. Stigma: Notes on the Management of Spoiled Identity. New York: Simon and Schuster, Inc.

Green, John C. 1999. "Development of the Christian Right." Pp. 153-167 in Waves of Protest: Social Movements Since the Sixties, edited by J. Freeman. Maryland: Rowman and Littlefield Publishers Inc. 
Goodstein, Laura. (2009). "More Atheists Shout It From the Rooftops." The New York Times. April 26.

Harris, Sam. 2005. The End of Faith: Religion, Terror, and the Future of Reason. New York: W.W. Norton \& Co.

Harris, Sam. 2006. Letter to a Christian Nation. New York: Random House

Hecht, Richard D. 2007. “Active versus Passive Pluralism: A Changing Style of Civil Religion?" The Annals of the American Academy of Political and Social Science. $612: 133-151$

Herberg, William. 1960. Protestant, Catholic, Jew: An essay in American religious sociology. Garden City, N.Y: Anchor Books.

Hitchens, Christopher. 2007. God is Not Great: How Religion Poisons Everything. New York: Twelve Philadelphia, PA: Da Capo.

Hout, Michael and Claude S. Fischer. 2002. "Why More Americans Have No Religious Preference: Politics and Generations." American Sociological Review. 67(2): 165-190.

Howard, Judith. 1991. "From Changing Selves Toward Changing Society. Pp. 209-233 in The Self-Society Dynamic : Cognition, Emotion, and Action, by J. Howard and P. Callero. Cambridge, England: Cambridge University Press.

Hunsberger, Bruce E. and Bob Altemeyer. 2006. Atheists: A Groundbreaking Study of America's Nonbelievers. Amherst, NY: Prometheus Books.

Hutchinson, Sikivu. 2011. Moral Combat: Black Atheists, Gender Politics, and the Values Wars. Infidel Books.

Hyman, Gavin. 2007. "Atheism in Modern History.” Pp. 27-44 in The Cambridge 
Companion to Atheism, edited by M. Martin. Cambridge, NY: Cambridge University Press.

Jaccarino, Mike, E. Sandovla, R. Schapiro. 2011. "9/11 Street Sign Named for Seven Fallen Firefighters Protested by Atheists." NY Daily News, July 6. Retrieved Nov. 10, 2011. http://articles.nydailynews.com/2011-0706/local/29759480_1_area-firefighters-community-board-bronstein Jacoby, Susan. 2004. Freethinkers: A History of Secularism in America. New York: Metropolitan Books.

Johnson, Burke. 1997. "Examining the Validity Structure of Qualitative Research." Education. 118(2): 282-292.

Lambert, Frank. 2008. Religion in American Politics. Princeton, NJ: Princeton University Press.

Larana, Enrique, H. Johnston, and J.R. Gusfield. 1994. "Identities, Grievances, and New Social Movements." Pp. 3-35 in New Social Movements, edited by E. Larana, H. Johnston, and J.R. Gusfield. Philadelphia, Temple University Press.

MacCallum, Martha. 2006. "Growing Atheist Movement in America." Fox News.

McGrath, Alister. 2004. The Twilight of Atheism. New York: Doubleday.

McKinley, James. 2010. "Texas: Atheist and Religious Bus Ads Banned in City.” New York Times, Dec. 16. Retrieved Nov. 10, 2011. http://www.nytimes.com/2010/12/17/us/17brfs-atheist.html?ref=atheism Miller, Alan S. and T. Nakamura. 1996. "On the Stability of Church Attendance Patterns during a Time of Demographic Change: 1965-1988." Journal for the Scientific Study of Religion 35(3): 275-284. 
Moore, R. Laurence. Religious Outsiders and the Making of Americans. New York. Oxford University Press.

Moszczynski, Joe. 2009. “Atheist's Protest Silences Lord's Prayer in N.J. Town Council." USA Today, January 16. Retrieved Nov. 10, 2011. http://www.usatoday.com/news/religion/2009-01-16-atheist-prayer_N.htm

Mullaney, Jamie L. 2005. Everybody Is Not Doing It: Abstinence and Personal Identity. Chicago: University of Chicago Press.

Norris, Pippa and Ronald Inglehart. 2004. Sacred and Secular: Religion and Politics Worldwide. New York: Cambridge University Press.

O'Hair, Madalyn M. 1969. What On Earth Is An Atheist. Austin: American Atheist Press. Peterson, Gregory. 2007. "Why the New Atheism Shouldn't Be (Completely) Dismissed." Zygon 42(4): 803-806.

Pew Research Forum. Religious Landscape Study. 2007. http://religions.pewforum.org/pdf/report-religious-landscape-study-full.pdf

Pew Forum on Religion and Public Life. 2009. "Faith in Flux: Changes in Religious Affiliation in the U.S." http://www.pewforum.org/Faith-in-Flux.aspx

Reger, Jo. 2007. "Where Are the Leaders? Music, Culture, and Contemporary Feminism." American Behavioral Scientist. 50(10): 1350-1369.

Ritchey, Jeff. 2009. “'One Nation Under God': Identity and Resistance in a Rural Atheist Organization." Journal of Religion and Popular Culture. 21(2).

Roberts, Kristal. 2010. “Atheist Group Protests the Donation of Equipment Purchased with Tax Dollars to Churches." ABC News, Dec. 29. Retrieved Nov. 10, 2011. http://www.abcactionnews.com/dpp/news/region_polk/atheist-group-protesting- 
the-donation-of-equipment-purchased-with-tax-dollars-to-churches

Roozen, David A. 1993. "Denominations Grow as Individuals Join Congregations." Pp. 15-34 in Church and Denominational Growth, edited by David A. Roozen and C. Kirk Hadaway. Nashville, TN: Abingdon Press.

Saxton, Alex. 2009. "The God Debates and the Materialist Interpretation of History." Science \& Society. 73(4): 474-497.

Schroer, Todd. 2008. "Technically Advanced in Communication: The Example of White Racialist 'Love Groups' and 'White Civil Rights Organizations'.” Pp. 77-100 in Identity Work in Social Movements, edited by J. Reger, D.J. Myers, and R.L. Einwohner. Minneapolis, MN: University of Minnesota Press.

Schutz, Amanda. 2012. "Coming Out of the 'Other' Closet: Applying the LGBT Experience to Atheists." Presented at the Annual Meeting of the Pacific Sociological Association, March 24, San Diego, California.

Sherman, Robert. 1988. Free Inquiry 8(4): 16.

Sherkat, Darren E. 2008. "Atheism, Agnosticism, and Theistic Certainty in the United States." Sociological Spectrum. 28(5): 438-459.

Smith, Christopher. 2011. "Becoming an Atheist in America: Constructing Identity and Meaning from the Rejection of Theism." Sociology of Religion. 72(2): 215-237.

Stenger, Victor J. 2009. The New Atheism: Taking a Stand for Science and Reason. Amherst, NY. Prometheus Books.

Strauss, Anselm and Juliet Corbin. 1998. Basics of Qualitative Research. Sage Publications.

Tarrow, Sidney G. 1998. Power in Movement: Social Movements and Contentious 
Politics. Cambridge, NY: Cambridge University Press.

Weiler-Harwell, Nina. 2008. “Attacking Atheists: Doing One's Duty to God and Country in $21^{\text {st }}$ Century America." PhD dissertation, Department of Political Science, University of Southern California.

Williams, Jim. 2008. “Atheists - An Increasingly Outspoken Minority.” CBS News Chicago.

Wilson, John F. 1979. Public Religion in American Culture. Philadelphia, Temple University Press.

Zuckerman, Phil. 2007. "Atheism: Contemporary Numbers and Patterns." Pp. 47-62 in The Cambridge Companion to Atheism, edited by M. Martin. Cambridge, NY: Cambridge University Press.

Zuckerman, Phil. 2008. Society Without God: What the Least Religious Nations Can Tell Us About Contentment. New York: New York University Press.

Zuckerman, Phil. 2009. "Atheism, Secularity, and Well Being: How the Findings of Social Science Counter Negative Stereotypes and Assumptions.” Sociological Compass 3(6): 949-971. 


\section{APPENDIX A: THE PARTICIPANTS}

\begin{tabular}{|c|c|c|c|c|c|c|}
\hline Participant & $\begin{array}{l}\text { Atheist group } \\
\text { participation }\end{array}$ & Sex & Age & Race & Education & $\begin{array}{l}\text { Grew up } \\
\text { in... }\end{array}$ \\
\hline Atheist 1 & $\begin{array}{l}\text { Non-group } \\
\text { member }\end{array}$ & Male & 25 & Caucasian & $\begin{array}{l}\text { Bachelors in } \\
\text { English (in } \\
\text { progress) }\end{array}$ & Montana \\
\hline Atheist 2 & $\begin{array}{l}\text { Non-group } \\
\text { member }\end{array}$ & Female & 24 & $\begin{array}{l}\text { Japanese/Caucasi } \\
\text { an }\end{array}$ & $\begin{array}{l}\text { Masters in } \\
\text { psychology (in } \\
\text { progress }\end{array}$ & Washington \\
\hline Atheist 3 & $\begin{array}{l}\text { Group } \\
\text { member }\end{array}$ & Male & 41 & Caucasian & $\begin{array}{l}\text { Masters in } \\
\text { electrical } \\
\text { engineering }\end{array}$ & Canada \\
\hline Atheist 4 & $\begin{array}{l}\text { Group } \\
\text { member }\end{array}$ & Male & 46 & Caucasian & $\begin{array}{l}\text { Bachelors in } \\
\text { journalism }\end{array}$ & Oregon \\
\hline Atheist 5 & Group leader & Male & 58 & Caucasian & $\begin{array}{l}\text { Masters in } \\
\text { journalism } \\
\text { (incomplete) }\end{array}$ & Midwest \\
\hline Atheist 6 & Group leader & Female & 43 & Caucasian & $\begin{array}{l}\text { Bachelors in } \\
\text { sociology }\end{array}$ & California \\
\hline Atheist 7 & $\begin{array}{l}\text { Group } \\
\text { member }\end{array}$ & Male & 42 & Caucasian & $\begin{array}{l}\text { Bachelors in } \\
\text { computer science }\end{array}$ & Oregon \\
\hline Atheist 8 & $\begin{array}{l}\text { Non-group } \\
\text { member }\end{array}$ & Female & 31 & African/Brazilian & $\begin{array}{l}\text { Bachelors in } \\
\text { business (in } \\
\text { progress) }\end{array}$ & Mississippi \\
\hline Atheist 9 & $\begin{array}{l}\text { Group } \\
\text { member }\end{array}$ & Male & 48 & Indian & $\begin{array}{l}\text { Masters in } \\
\text { environmental } \\
\text { science }\end{array}$ & India \\
\hline Atheist 10 & $\begin{array}{l}\text { Non-group } \\
\text { member }\end{array}$ & Male & 38 & Caucasian & $\begin{array}{l}\text { Masters in } \\
\text { sociology (in } \\
\text { progress) }\end{array}$ & California \\
\hline Atheist 11 & $\begin{array}{l}\text { Group } \\
\text { member }\end{array}$ & Male & 36 & Caucasian & $\begin{array}{l}\text { Three years } \\
\text { community } \\
\text { college }\end{array}$ & Idaho \\
\hline Atheist 12 & $\begin{array}{l}\text { Group } \\
\text { member }\end{array}$ & Female & 22 & Caucasian/Jewish & $\begin{array}{l}\text { Associates of } \\
\text { arts }\end{array}$ & Oregon \\
\hline Atheist 13 & Group leader & Male & 43 & Caucasian & $\begin{array}{l}\text { Bachelors of } \\
\text { science }\end{array}$ & Oregon \\
\hline Atheist 14 & $\begin{array}{l}\text { Non-group } \\
\text { member }\end{array}$ & Male & 30 & $\begin{array}{l}\text { Hispanic/Caucasi } \\
\text { an }\end{array}$ & $\begin{array}{l}\text { Bachelors of } \\
\text { sociology (in } \\
\text { progress) }\end{array}$ & D.C. \\
\hline Atheist 15 & $\begin{array}{l}\text { Non-group } \\
\text { member }\end{array}$ & Female & 35 & Caucasian & $\begin{array}{l}\text { Bachelors in } \\
\text { child and family } \\
\text { studies }\end{array}$ & $\begin{array}{l}\text { New } \\
\text { Hampshire }\end{array}$ \\
\hline
\end{tabular}




\section{APPENDIX B: INTERVIEW GUIDE}

Age?

How far did you go in school?

What race do you identify with?

Where did you grow up?

Do you identify as an atheist?

Prompts: Do you identify as any other form of non-believer: humanist, secularist, rationalist, etc.

What does being an atheist mean to you? Or, How do you define what it is to be an atheist?

Prompts: Are you certain God doesn't exist? Do you believe any spiritual or supernatural forces? Do you think there is a chance that you are wrong? If presented with evidence of a god, would you change your mind?

When did you begin to think of yourself as an atheist?

Prompts: Would you say you were "raised atheist?" When you were presented with the idea, was it in a negative or a positive context? Do you think your experience is typical? Do you talk to other people about your beliefs?

Prompts: Who? Do you associate with mostly other atheists, a mix, or mostly religious people?

Have you ever had to defend your beliefs to others?

Prompts: How often do you find yourself doing this? To whom do you defend them to? What is your defense? Do you find yourself shying away from doing this?

Do you read any atheist authors/publications?

Prompts: If yes: When did you start? Did reading change your thinking about being an atheist? What do you like most about that author/publication? Are there any atheist authors/publications that you disagree with? What do you think those authors offer atheists?

If no: Are you familiar with any atheist authors/publications? Have you heard of Hitchens, Dawkins, O'Hair, Harris, Flew; Freedom from Religion Foundations (billboards), American Atheists? Are you familiar with any of their main arguments?

Are you a member of any atheist groups?

Prompts: If yes: How long have you been a member? Why did you join? What do you get out of being in the group? Are there things about the group that you dislike or would change?

If no: Why aren't you in a group? Would you consider joining one?

Final prompt for either: Do you get information about atheism from any sources other than published material or group interaction (blogs[Reddit, Atheist Nexus], friends outside of groups)?

What is your stance on religious tolerance?

Do you think atheists are tolerant of religion? Do you think atheists should be tolerant of religion? Do you see positives in religion?

\section{Atheism as an identity movement}

Prompts: Do you think atheists should "come out"? How would you define "activist"?

Do you consider yourself an activist? What kinds of activism have you participated in? 
What would it take for you to engage in more activism? What do you think atheists should do, if anything? Would it help if atheists relabeled themselves? Are you aware of any other social movements that you think atheists should copy? Do you think atheists are/should be building a community? What kind of community is/should be built? Are there forms of atheism you don't agree with? How do you think that affects atheism as an identity and a movement? 


\section{APPENDIX C: CODING SHEET}

Why take action?

Why now?

How do they define the scene?

Who do they identify as major actors?

What do they say to do (what actions to take)?

How do they show that action will make a difference?

How do they treat atheists who fail to be loyal dramaturgically?

Who do they label as the antagonists?

How do they frame the antagonist?

What is the tone of the publication?

What is the purpose?

What kind of atheism is presented as good?

How do they address the alienating aspect of atheism? Ie - do they address an atheist community?

Are they emphasizing sameness or difference?

Critique or education? 